Washington University School of Medicine Digital Commons@Becker

Open Access Publications

$11-19-2007$

\title{
Site-1 protease is essential for endochondral bone formation in mice
}

\author{
Debabrata Patra \\ Washington University School of Medicine at Barnes-Jewish Hospital \\ Xiaoyun Xing \\ Washington University School of Medicine at Barnes-Jewish Hospital \\ Sherri Davies \\ Washington University School of Medicine at Barnes-Jewish Hospital \\ Jennifer Bryan \\ Washington University School of Medicine at Barnes-Jewish Hospital \\ Carl Franz \\ Washington University School of Medicine at Barnes-Jewish Hospital
}

See next page for additional authors

Follow this and additional works at: https://digitalcommons.wustl.edu/open_access_pubs

Part of the Medicine and Health Sciences Commons

Please let us know how this document benefits you.

\section{Recommended Citation}

Patra, Debabrata; Xing, Xiaoyun; Davies, Sherri; Bryan, Jennifer; Franz, Carl; Hunziker, Ernst B.; and Sandell, Linda J., "Site-1 protease is essential for endochondral bone formation in mice." The Journal of Cell Biology. 179, 4. 687-700. (2007).

https://digitalcommons.wustl.edu/open_access_pubs/567

This Open Access Publication is brought to you for free and open access by Digital Commons@Becker. It has been accepted for inclusion in Open Access Publications by an authorized administrator of Digital Commons@Becker. For more information, please contact vanam@wustl.edu. 


\section{Authors}

Debabrata Patra, Xiaoyun Xing, Sherri Davies, Jennifer Bryan, Carl Franz, Ernst B. Hunziker, and Linda J. Sandell 


\title{
Site-1 protease is essential for endochondral bone formation in mice
}

\author{
Debabrata Patra, ${ }^{1}$ Xiaoyun Xing, ${ }^{1}$ Sherri Davies, ${ }^{1}$ Jennifer Bryan, ${ }^{1}$ Carl Franz, ${ }^{1}$ Ernst B. Hunziker, ${ }^{3}$ \\ and Linda J. Sandell, ${ }^{1,2}$ \\ 'Department of Orthopaedic Surgery and 2Department of Cell Biology and Physiology, Washington University School of Medicine at Barnes-Jewish Hospital, \\ St. Louis, MO 63110 \\ International Team for Implantology Research Institute, University of Bern, Bern 3010, Switzerland
}

S ite- 1 protease (S1P) has an essential function in the conversion of latent, membrane-bound transcription factors to their free, active form. In mammals, abundant expression of SIP in chondrocytes suggests an involvement in chondrocyte function. To determine the requirement of S1P in cartilage and bone development, we have created cartilage-specific S1P knockout mice (S1 Pcko). S1Pcko mice exhibit chondrodysplasia and a complete lack of endochondral ossification even though Runx2 expression, Indian hedgehog signaling, and osteoblastogenesis is intact. However, there is a substantial increase in chon-

\section{Introduction}

Endochondral ossification is the process by which most long bones of the body are formed (Provot and Schipani, 2005). During endochondral ossification, mesenchymal cells first aggregate to form condensations (Hall and Miyake, 2000). The cells in the center of these condensations differentiate into chondrocytes, forming the cartilaginous template, whereas the undifferentiated cells at the periphery form the surrounding perichondrium (Horton, 1993). After formation of the cartilage template, the innermost chondrocytes differentiate into hypertrophic chondrocytes and the cells of the inner layer of the perichondrium

Correspondence to D. Patra: patrad@wudosis.wustl.edu; or L.J. Sandell: sandelll@wudosis.wustl.edu

S. Davies' current address is Division of Oncology, Washington University School of Medicine, St. Louis, MO 63110.

E.B. Hunziker's current address is Department of Cranio-Maxillofacial Surgery and Department of Clinical Research, University of Bern, Bern 3010, Switzerland.

Abbreviations used in this paper: Agcl, aggrecan; ATF6, activating transcription factor 6; BiP, immunoglobulin heavy chain binding protein; $B S P$, bone sialoprotein; Col I, type I collagen; CREBH, cAMP-responsive element binding protein $\mathrm{H}$; $\mathrm{E}$, embryonic day; ERSS, ER stress signaling; IHC, immunohistochemistry; lhh, Indian hedgehog; MMP, matrix metalloproteinase; OASIS, old astrocyte specifically induced substance; PECAM-1, platelet/endothelial cell adhesion molecule 1; Ptc-1, Patched-1; PTHrP, parathyroid hormone-related peptide; S1P, site-1 protease; SCAP, SREBP cleavage-activating protein; SREBP, sterol regulatory element binding protein; WT, wild type.

The online version of this article contains supplemental material.

(c) The Rockefeller University Press $\$ \mathbf{\$ 3 0 . 0 0}$

The Journal of Cell Biology, Vol. 179, No. 4, November 19, 2007 687-700 http://www.jcb.org/cgi/doi/10.1083/jcb.200708092 drocyte apoptosis in the cartilage of S1 ${ }^{\text {cko }}$ mice. Extraction of type II collagen is substantially lower from S1 Pcko cartilage. In S1 Pcko mice, the collagen network is disorganized and collagen becomes entrapped in chondrocytes. Ultrastructural analysis reveals that the endoplasmic reticulum (ER) in S1Pcko chondrocytes is engorged and fragmented in a manner characteristic of severe ER stress. These data suggest that S1P activity is necessary for a specialized ER stress response required by chondrocytes for the genesis of normal cartilage and thus endochondral ossification.

differentiate into osteoblasts (Komori et al., 1997; Otto et al., 1997), forming a bone collar around the cartilaginous core (Caplan and Pechak, 1987). The hypertrophic cells secrete a distinct ECM that gradually becomes calcified (Poole, 1991). This specialized matrix allows for vascular invasion from the bone collar and the entry of osteoclasts and osteoblasts that degrade the mineralized cartilage matrix and deposit bone (Ortega et al., 2003). Apoptosis of hypertrophic cells and the deposition of a matrix rich in type I collagen ( $\mathrm{Col} \mathrm{I}$ ) results in two opposing growth plates that allow for longitudinal bone growth in both directions. This process is in contrast to the craniofacial skeleton bones that are formed by intramembranous ossification, where mesenchymal cells directly differentiate into bone without an intermediate cartilage template.

In this paper, we have identified site-1 protease (S1P) as a new player involved in regulating endochondral ossification. S1P (also known as membrane-bound transcription factor protease, site 1) is a proprotein convertase and a key member of the regulated intramembrane proteolysis pathway involved in the unfolded protein response and cholesterol homeostasis (Brown et al., 2000). A role for S1P in cartilage development was shown through the study of the zebrafish gonzo mutant (Schlombs et al., 2003), which has both lipid and skeletal abnormalities. S1P plays a critical role in the processing of the sterol regulatory element 
binding proteins (SREBP-1a, -1c, and -2; Eberle et al., 2004). SREBPs are membrane-bound transcription factors in the ER and regulate cholesterol and fatty acid biosynthesis and uptake. When cholesterol levels are high, SREBP is retained in the ER membrane as a complex with the sterol-sensing protein SREBP cleavage-activating protein (SCAP) and the retention protein INSIG (insulin induced gene). When cholesterol levels drop, the SREBP-SCAP complex dissociates from INSIG and translocates to the Golgi bodies, where SREBP is sequentially cleaved by S1P and S2P to release the amino-terminal domain of SREBP containing the basic helix-loop-helix leucine zipper region. The basic helix-loop-helix leucine zipper region translocates to the nucleus to bind to cis-acting sterol responsive elements. In a similar fashion, S1P is also involved in the activation of other ER membrane-bound proteins such as activating transcription factor 6 (ATF6; Haze et al., 1999; Ye et al., 2000), old astrocyte specifically induced substance (OASIS; Murakami et al., 2006), and cAMP-responsive element binding protein $\mathrm{H}(\mathrm{CREBH}$; Zhang et al., 2006), which are transcription factors for the unfolded protein response target genes.

To elucidate the role of S1P in all aspects of skeletal development, we created cartilage-specific S1P knockout mice $\left(\mathrm{S} 1 \mathrm{P}^{c k o}\right)$ using a Col2al promoter. $\mathrm{S}^{\mathrm{P}} \mathrm{P}^{c k o}$ mice die shortly after birth and exhibit severe chondrodysplasia. The cartilage matrix is abnormal in $\mathrm{S}^{\mathrm{P}} \mathrm{P}^{c k o}$ mice with defects in Col II protein secretion and assimilation into the matrix, and endochondral bone formation is completely absent. This is the first example of a defect in a regulated intramembrane proteolysis enzyme that affects cartilage development and endochondral ossification in mice. Deletions of various matrix metalloproteinases (MMPs), such as MMP13 or MMP9 (Inada et al., 2004; Stickens et al., 2004), thought to be important in bone morphogenesis did not abolish endochondral ossification. Thus, S1P is a unique enzyme that plays an integral role in skeletal development.

\section{Results}

S1Pcko mice exhibit severe chondrodysplasia To produce mice lacking S1P in the cartilage, the Col2-Cre recombinase was used to delete exon 2 of S1P. S1P ${ }^{f /+}$;Col2-Cre mice were bred with $\mathrm{S} \mathrm{P}^{\mathrm{f} / f}$ mice to generate conditional knock-

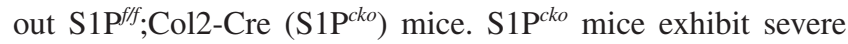
chondrodysplasia (Fig. 1 A) with deformed limbs, a protruding tongue (Fig. 1 B), and a distended belly and die during or shortly after birth. All structural elements are present in $\mathrm{S} \mathrm{P}^{c k o}$ mice but are considerably smaller than in wild-type (WT) mice (Fig. 1 C). Fig. 1 D shows a detailed analysis of the skeletal elements. The smaller skull in $\mathrm{S}_{1} \mathrm{P}^{c k o}$ mice, caused by a shortened chondocranial base coupled with foreshortened mandibles and upper jaw bones, appears to be responsible for the protrusion of the tongue. The skull bones show increased sensitivity to potassium hydroxide (used for clearing the tissue during skeletal staining)
A

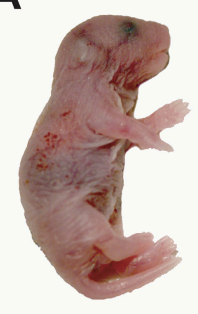

B

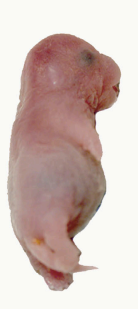

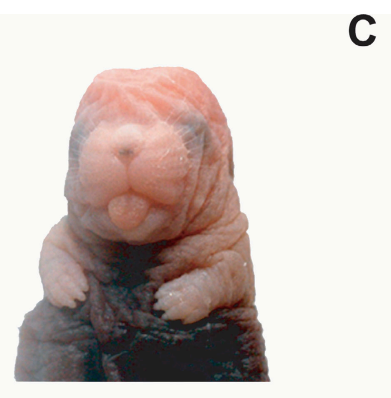

C

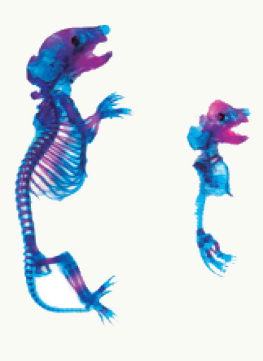

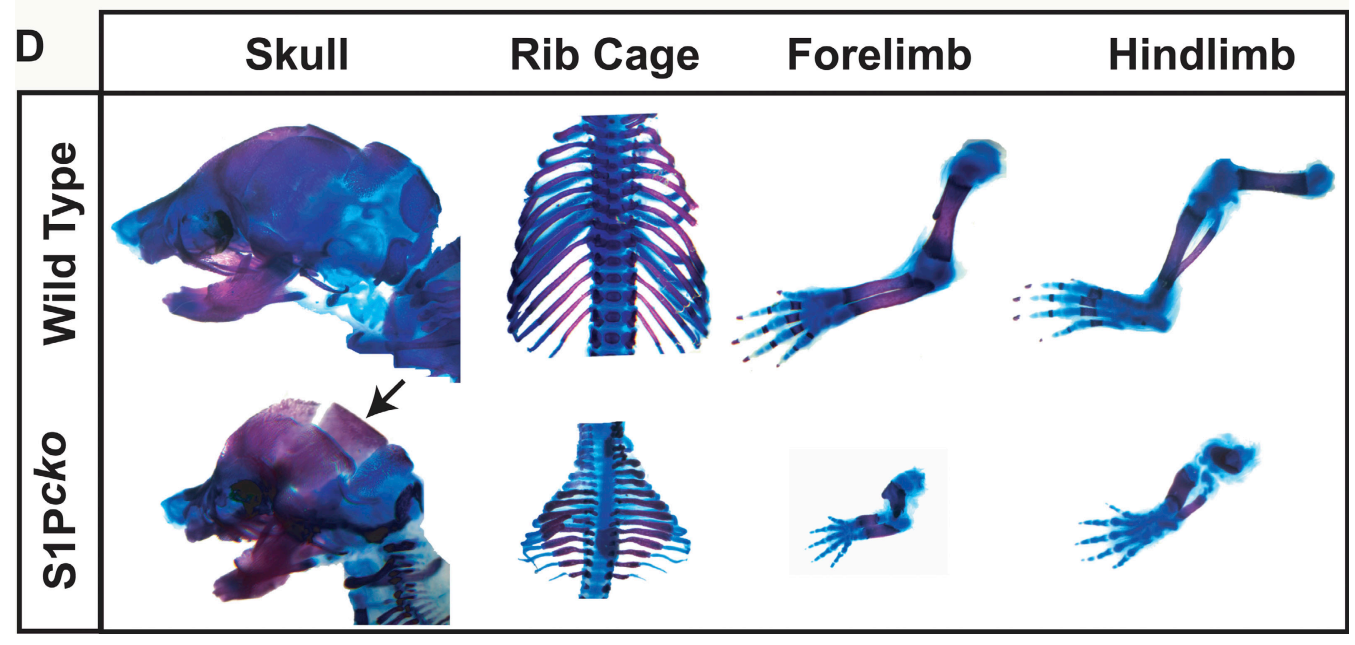

Figure 1. Severe chondrodysplasia in S1Pcko mice. (A) Newborn S1Pcko mice (right) exhibit severe chondrodysplasia as compared with WT mice (left). (B) S1Pcko mice have a smaller skull and foreshortened mandibles, which results in the protrusion of the tongue. (C) Whole animal skeletal preparation of WT (left) and S1Pcko (right) newborns. (D) The skeletal patterning in S1Pcko mice is similar to WT mice, but all the skeletal elements are smaller. The arrow points to the furrow that is formed in S1Pcko skull (absent in WT) during skeletal staining, which suggests a lack of structural integrity of the skull bones. 
that resulted in the dissolution of the bones in the back of the skull (Fig. 1 D, arrow), which remain intact in the WT. The chest cavity is small and presses the internal organs into the abdominal cavity, giving the belly a distended appearance. The smaller chest cavity probably causes acute neonatal respiratory distress and subsequent lethality. The skewed orientation of the limbs, particularly the hind limbs, suggests anomalous articular joint

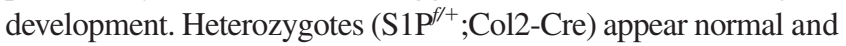
do not show any phenotype (unpublished data).

To confirm that the phenotype in $\mathrm{S} \mathrm{P}^{c k o}$ mice is caused by a lack of S1P, we analyzed the expression of the $S 1 P$ gene in chondrocytes in different developmental stages by in situ hybridization (Fig. 2). SIP is abundantly expressed in the chondrocytes in the developing WT forelimb at all stages (Fig. 2, A-D). The heterozygotes show drastic reduction in $S 1 P$ expression in chondrocytes but show normal bone development, with expression in bone and surrounding tissues intact (Fig. 2, E and F). As expected, the homozygous knockout $\left(\mathrm{S} \mathrm{P}^{c k o}\right)$ does not show any $S 1 P$ expression in skeletal tissues (Fig. $2 \mathrm{H}$ ). These data suggest that the mutant phenotype could be directly attributed to the efficient knockout of both copies of S1P in the cartilage in $\mathrm{S}_{1} \mathrm{P}^{c k o}$ mice.

\section{Lack of organized hypertrophy and endochondral ossification in S1Pcko mice}

As S1P ${ }^{c k o}$ mice die during or shortly after birth, we conducted a histological analysis of various skeletal elements at different embryonic stages. S1P ${ }^{c k o}$ mice lack an organized hypertrophic zone and endochondral ossification, as shown for the humerus at different stages (Fig. 3). At embryonic day (E) 13.5, no major differences are observed in the morphology of the humerus between $\mathrm{S} 1 \mathrm{P}^{c k o}$ and WT mice. At E13.75 (7 h after E13.5), the WT humerus increased in size and the chondrocytes in the center initiated hypertrophy. S1P ${ }^{c k o}$ mice, however, showed only a slight increase in the size of the humerus at E13.75. The transition from proliferating to hypertrophic cells appears to be initiated but does not progress to hypertrophy, though a change in morphology of the cells at the center of the humerus is noticeable. At E14.5, the humerus in WT mice has considerably increased in size and hypertrophy is completely established. In $\mathrm{S}_{1} \mathrm{P}^{c k o}$ mice, however, the transition from proliferating to hypertrophic cells is still incomplete at E14.5. At E15.5, endochondral bone is observed in WT mice with the establishment of a growth plate. However, at E15.5, $\mathrm{S}_{1} \mathrm{P}^{c k o}$ mice still do not exhibit an organized hypertrophic zone. Notably, there is no endochondral ossification or growth plate, and, consequently, the humerus is small compared with the WT. In the absence of endochondral bone, however, there is an exuberant growth of the bone collar (Fig. 3, arrow).

At E18.5, it is clear that $\mathrm{S}^{\mathrm{c}} \mathrm{P}^{c k}$ mice suffer from a lack of endochondral bone formation and a structured growth plate, rather than a delay. At this stage, the exuberant bone collar often impinges into the diaphysis and bisects it. A lack of endochondral ossification is also observed in the hind limbs, sternum, ribs, and spine (Fig. S1, available at http://www.jcb.org/cgi/content/ full/jcb.200708092/DC1). Although a hypertrophic zone is not seen in $\mathrm{S} \mathrm{P}^{c k o}$ mice, they have the ability to make hypertrophic cells, which is more distinguishable in later developmental stages (Fig. S2). In summary, a lack of organized endochondral ossification is observed in all skeletal elements in $\mathrm{S}_{1} \mathrm{P}^{c k o}$ mice because of the disruption of S1P activity.

\section{Indian hedgehog (Ihh) signaling is intact in S1Pcko mice}

Because of a lack of endochondral ossification in $\mathrm{S}^{\mathrm{P}} \mathrm{P}^{c k o}$ mice, we examined Ihh signaling, which is known to be an essential regulator of chondrocyte proliferation and hypertrophic differentiation. Ihh's function is thought to be dependent on lipophilic modifications critical for the spatially restricted localization of Ihh signaling (Gritli-Linde et al., 2001). In the growth plate, Ihh
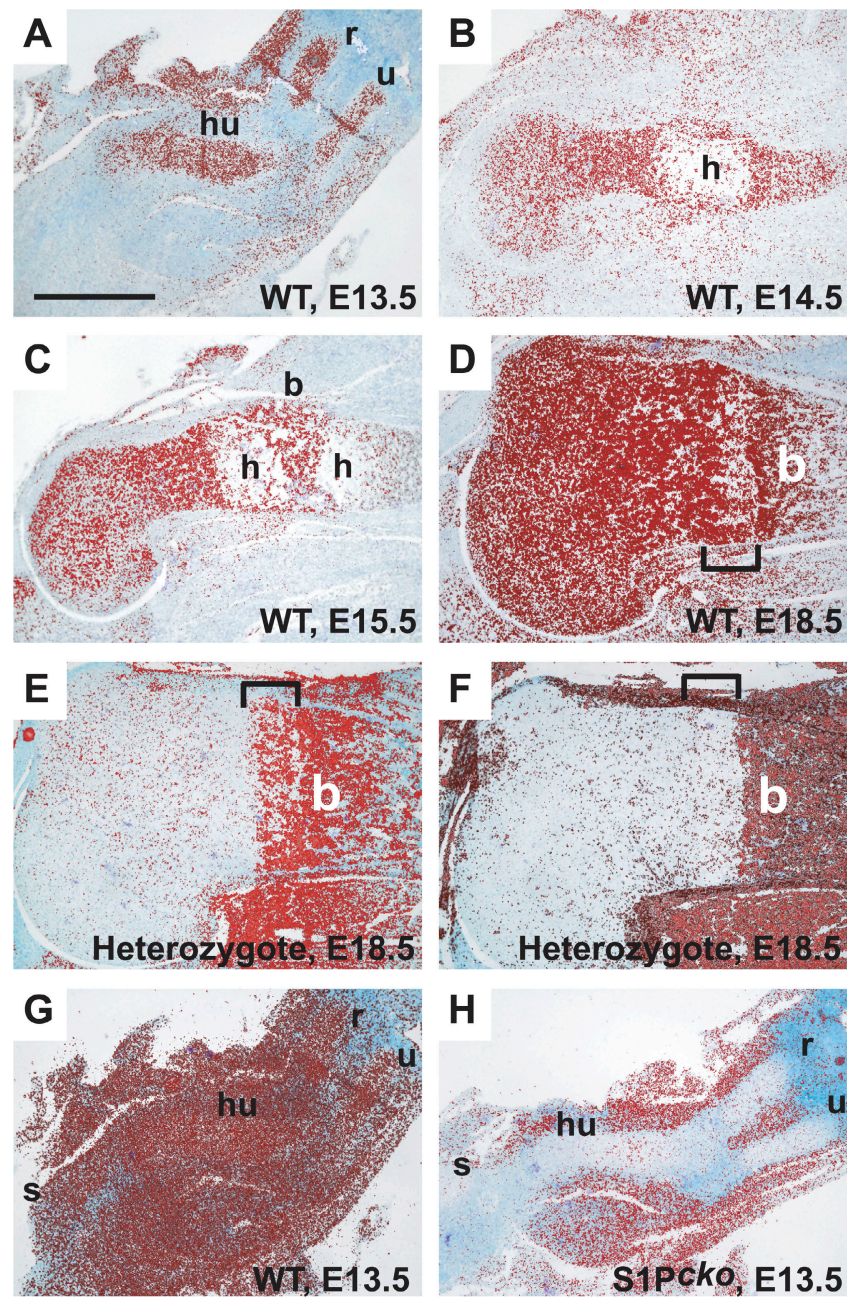

Figure 2. In situ hybridization analysis of SIP gene. Expression of SIP is ubiquitous, although expression is stronger in the skeletal elements with use of the full-length SIP in situ probe (A-E). (A) SIP is expressed abundantly in immature chondrocytes in the humerus (hu), radius $(r)$, and ulna $(u)$ in the forelimb of the WT at E13.5. (B) At E14.5, expression of S1P decreases considerably in the hypertrophic (h) chondrocytes in the humerus of the WT. (C) At E15.5, expression of SIP is seen in the newly deposited bone (b) in the WT. (D) At E18.5, expression of SIP is seen throughout the humerus, including the hypertrophic cells (bracket) and bone trabeculae in the WT. (E) Expression of SIP is drastically reduced in the chondrocytes of the heterozygotes $\left(\mathrm{S}^{\mathrm{f} / \mathrm{P}^{+}}\right.$;Col2-Cre) but is normal in bone and surrounding tissue (E18.5) using the full-length probe or against exon 2 of SIP (F). Brackets indicate hypertrophic cells. In situ analysis for SIP using the exon 2 probe in E13.5 WT (G) and S1Pcko $(H)$ forelimb. In S1 ${ }^{c k o}$ mice, expression signaling from exon 2 is absent in the skeletal tissues. s, scapula. Bar, $500 \mu \mathrm{m}$. 


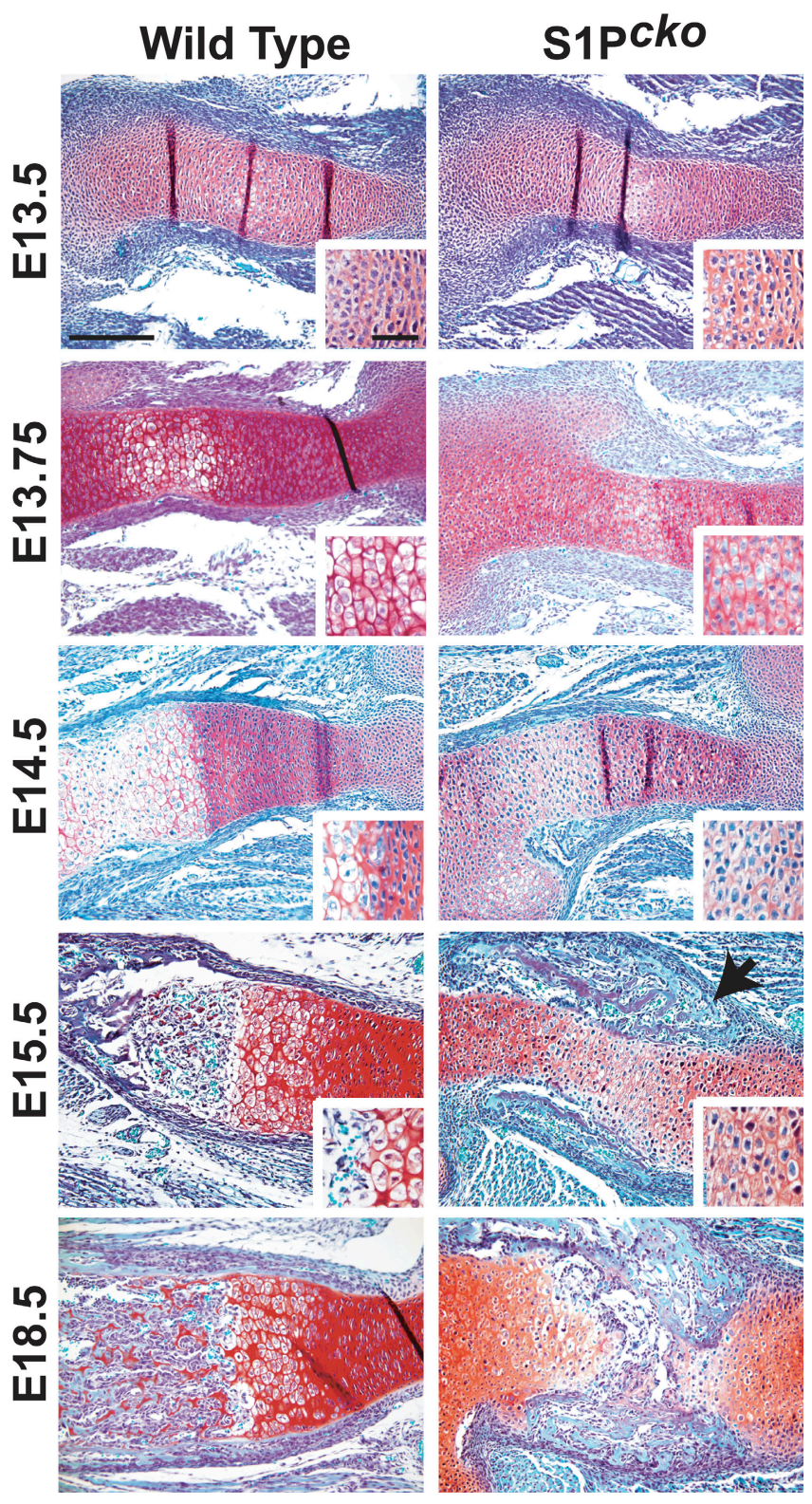

Figure 3. Lack of organized hypertrophy and endochondral bone formation in S1Pcko mice. WT and S1Pcko forelimb sections were stained with Safranin $\mathrm{O}$, Fast green, and hematoxylin at various time points. The humerus is shown in all panels. Hypertrophic chondrocytes are visible in WT mice as early as E13.75 (7 h after E13.5). These hypertrophic cells are structured into a distinct hypertrophic zone that is missing in S1Pcko mice. Endochondral bone is evident in WT but absent in S1Pcko mice at E15.5; in the absence of endochondral bone, an exuberant bone collar is formed (arrow). At E18.5, the exuberant bone collar often impinges into the diaphysis and bisects the cartilage. Bar, $200 \mu \mathrm{m}$. (insets) High magnification pictures showing the morphology of the chondrocytes near the center of the limb at E13.5; the morphology of hypertrophic cells at E13.75; the junction of the proliferating and hypertrophic cells at E14.5; the junction of the bone and hypertrophic cells for WT; and the center of the limb for the mutant at E15.5. Bar, $50 \mu \mathrm{m}$.

is distributed in a gradient that is necessary for coordinated chondrocyte proliferation and differentiation (Koziel et al., 2004). As cholesterol and fatty acid synthesis is likely to be affected in chondrocytes because of the absence of S1P, it could lead to defects in Ihh signaling. A defect in Ihh signaling is associated with a decrease in chondrocyte proliferation (St-Jacques et al., 1999). Thus, to analyze the nature of Ihh signaling in our model, we labeled proliferating chondrocytes with BrdU at E14.5 (Fig. 4, A and B). Notably, at E14.5, analysis of the proliferating BrdU-labeled cells revealed that both WT and S1P $\mathrm{P}^{c k o}$ mice exhibit nearly identical rates of proliferation (Fig. 4 C). Moreover, WT and S1P ${ }^{c k o}$ proliferating chondrocytes displayed the ability to exit the cell cycle, as seen by a lack of BrdU incorporation as they progressed toward hypertrophic differentiation (Fig. 4, A and B).

The Ihh null mutant is also characterized by a lack of expression of its receptor and transcriptional target Patched-1 (Ptc-1) and parathyroid hormone-related peptide (PTHrP; St-Jacques et al., 1999). PTHrP and its receptor PTHrP-R play important roles in the control of hypertrophic differentiation (Lanske et al., 1996; Schipani et al., 1997). Therefore, we analyzed the expression of $P t c-1$ and $P T H r P$ in $\mathrm{S}_{1} \mathrm{P}^{c k o}$ mice by in situ hybridization. Expression of both Ptc-1 (Fig. 4 E) and PTHrP (Fig. 4 G) is seen in $\mathrm{S} \mathrm{P}^{c k o}$ mice, though the expression of Ptc-1 is not completely similar to WT mice and PTHrP appears slightly reduced. Ihh is also required to establish the bone collar by regulating the differentiation of the perichondrial mesenchymal cells into osteoblast progenitors (St-Jacques et al., 1999). Consequently, Ihh null mutants do not form a bone collar. Therefore, we studied bone collar formation at E13.5 by analyzing the expression of bone sialoprotein $(B S P)$, a major structural protein of the bone matrix specifically expressed by maturing osteoblasts. Notably, both WT and $\mathrm{S}^{\mathrm{P}} \mathrm{P}^{c k o}$ mice displayed a timely expression of BSP in the developing bone collar at E13.5 (Fig. 4, $\mathrm{H}$ and I). Collectively with $\mathrm{Ptc}-1$ and $\mathrm{PTHrP}$ expression, these data suggest that Ihh signaling is intact in $\mathrm{S}_{1} \mathrm{P}^{c k o}$ mice.

\section{Hypertrophic chondrocyte differentiation is incomplete in S1P ${ }^{c k o}$ mice}

Hypertrophic differentiation begins with the proliferating chondrocytes exiting the cell cycle and beginning to express $I h h$ and Runx 2 to form the prehypertrophic cells, which exhibit a decreased expression of Col2. The fully differentiated hypertrophic chondrocytes are large, no longer express Col2, and are characterized by the expression of Collo and VEGF. In S1P $\mathrm{S}^{c k o}$ mice, hypertrophic differentiation is initiated as chondrocytes exit the cell cycle and no longer incorporate BrdU (Fig. 4 B). However, under higher magnification, this region in E14.5 S1P $\mathrm{P}^{c k o}$ mice does not show the same morphology as in the WT (Fig. 5). In the WT humerus (Fig. 5 A), there is a clear definition of the hypertrophic zone. Above the hypertrophic zone, proliferating chondrocytes are seen organized in groups of columnar chondrocytes. Between these groups, there is an abundant matrix that stains a deep red. In S1P $\mathrm{P}^{c k o}$ mice (Fig. $5 \mathrm{~B}$ ), however, columnar organization of the cells is absent. Chondrocytes are present in a random configuration and are more densely packed. Although a few enlarged cells are present, a distinct hypertrophic zone is absent.

To analyze hypertrophic differentiation in $\mathrm{S}_{1} \mathrm{P}^{c k o}$ mice, we performed a series of in situ hybridizations on E14.5 humerus serial sections. First, we analyzed the expression of Runx2. Runx2 is a powerful positive regulator of chondrocyte maturation into hypertrophy, and Runx 2 null mice exhibit an absence of both endochondral and intramembranous ossification because of an 

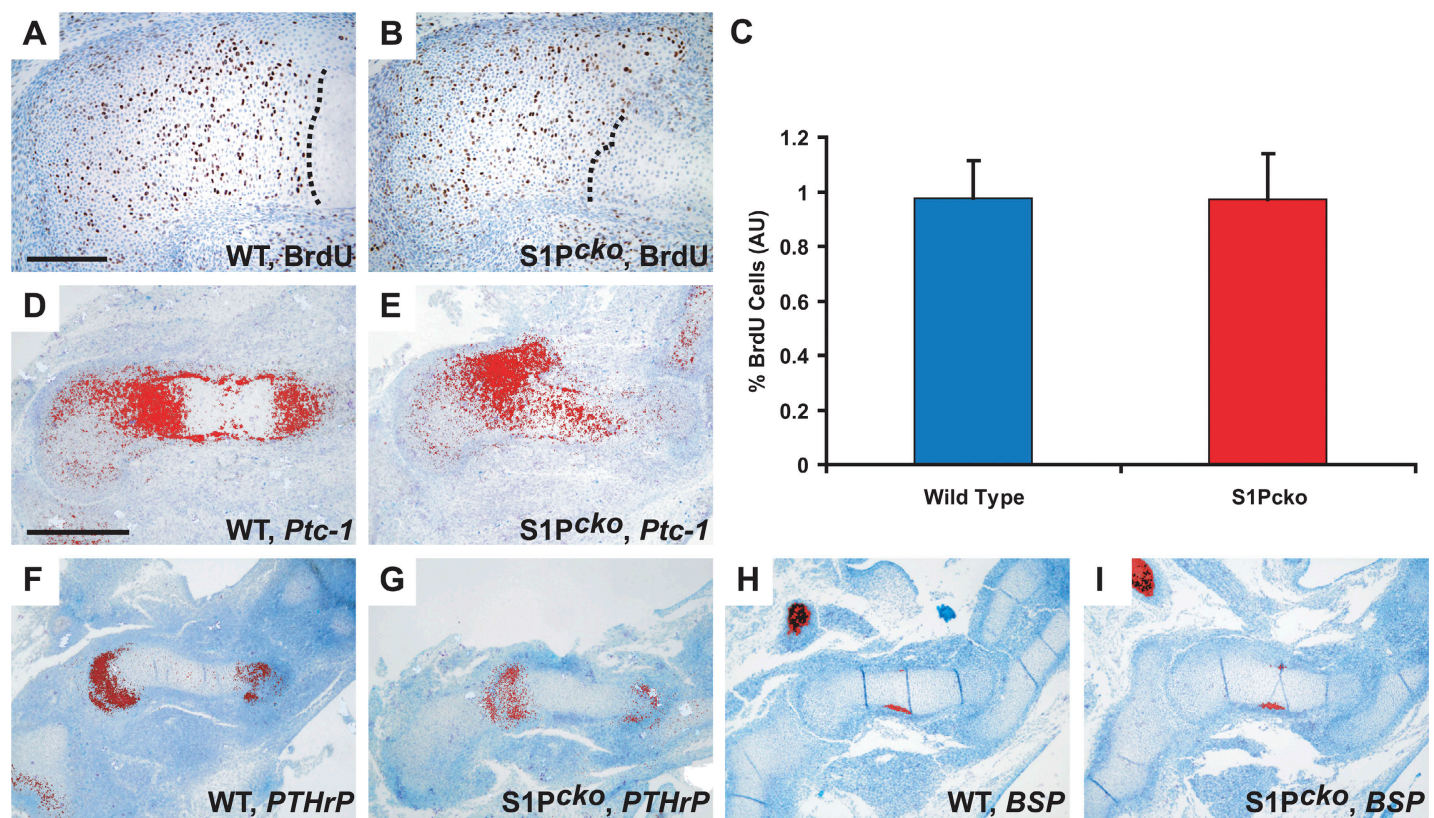

Figure 4. Intact Ihh signaling in S1Pcko mice. (A and B) IHC with anti-BrdU antibodies, showing the presence of actively proliferating, BrdU-labeled chondrocytes in the proximal region of the humerus in WT (A) and S1Pcko (B) mice. In both WT and S1Pcko mice, the initiation of hypertrophic differentiation caused by exit from the cell cycle is visible as a lack of BrdU incorporation (the dotted line marks the end of BrdU incorporation). (C) BrdU incorporation in the proximal region of the humerus in WT and S1Pcko mice, shown here as a percentage of BrdU-positive nuclei in the proliferative zone at E14.5. Error bars represent mean + SD. The WT value is arbitrarily assigned as 1. (D-I) In situ hybridization analyses for Ptc-1 at E14.5 (D and E), PTHrP at E13.5 (F and G), and BSP at E13.5 ( $\mathrm{H}$ and I) suggesting the presence of intact lhh signaling in S1Pcko mice. Bars: (A and B) $200 \mu \mathrm{m}$; (D-I) $500 \mu \mathrm{m}$.

arrest in osteoblastogenesis (Ducy et al., 1997; Komori et al., 1997). By in situ analysis, $\mathrm{S} \mathrm{P}^{c k o}$ mice showed an expression pattern for Runx2 that is similar to the WT in that expression is seen in the perichondrium and presumptive prehypertrophic and hypertrophic cells (Fig. 5, C and D). To better define the prehypertrophic and hypertrophic regions, we analyzed the expression of
Ihh and PTHrP-R in prehypertrophic cells and Collo, which is expressed only by hypertrophic cells. In WT mice, the Ihh(Fig. $5 \mathrm{E}$ ) and PTHrP-R-expressing (Fig. $5 \mathrm{G}$ ) prehypertrophic cells and the Collo-expressing (Fig. 5 I) hypertrophic cells form well-defined regions, with the prehypertrophic cells always lying proximal (from the humerus head) to the hypertrophic cells.

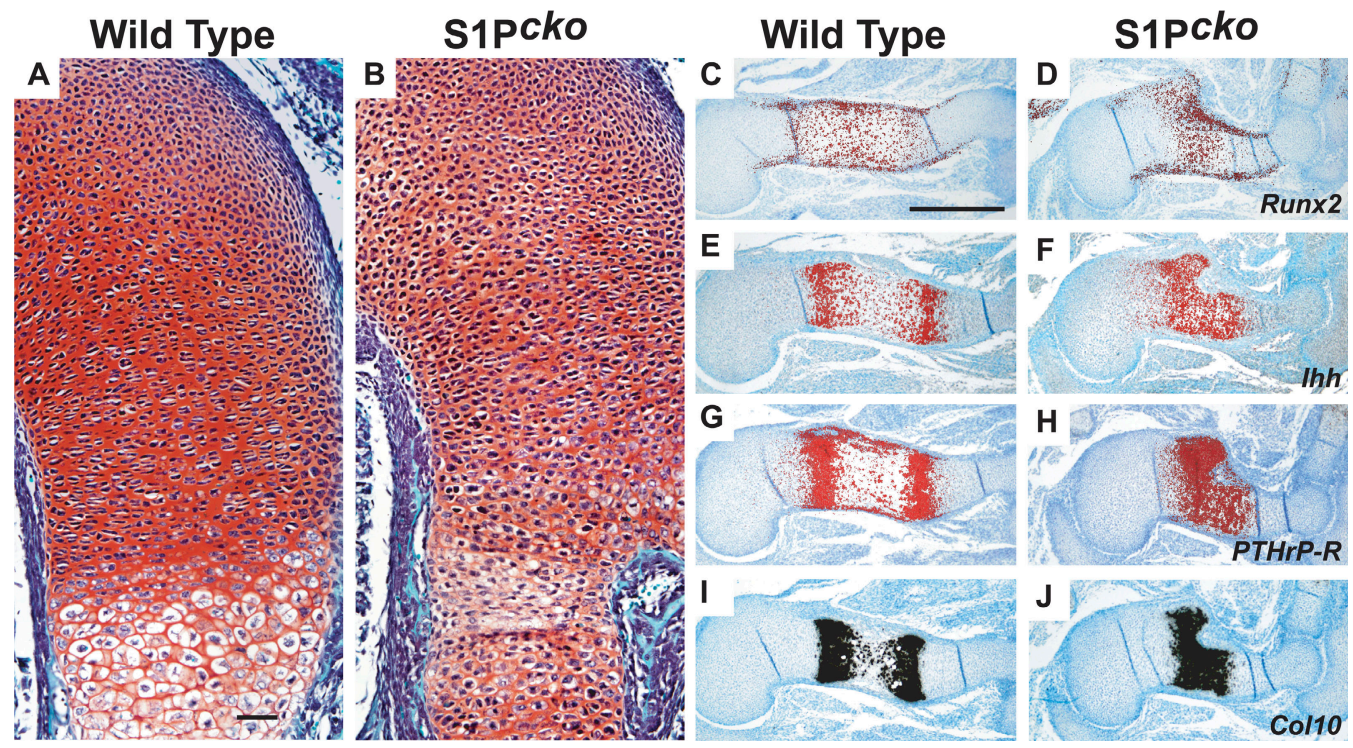

Figure 5. A molecular analysis of hypertrophic differentiation in S1Pcko mice. The prehypertrophic and hypertrophic zones in S1 Pcko mice are not well defined. (A and B) The humerus of WT (A) and S I Pcko (B) mice at E14.5 was stained with Safranin O, Fast green, and hematoxylin. The proliferative to hypertrophic zones are shown in both cases. The chondrocytes are randomly oriented in SIPcko mice and do not acquire the characteristic hypertrophic phenotype seen in the WT in spite of Runx2 (D) and CollO (J) expression. In situ hybridization analyses in adjacent sections of the WT and S1Pcko humerus at E14.5 for Runx2 (C and D), Ihh (E and F), PTHrP-R (G and H), and Collo (I and J). Bars: (A and B) $50 \mu \mathrm{m}$; (C-J) $500 \mu \mathrm{m}$. 

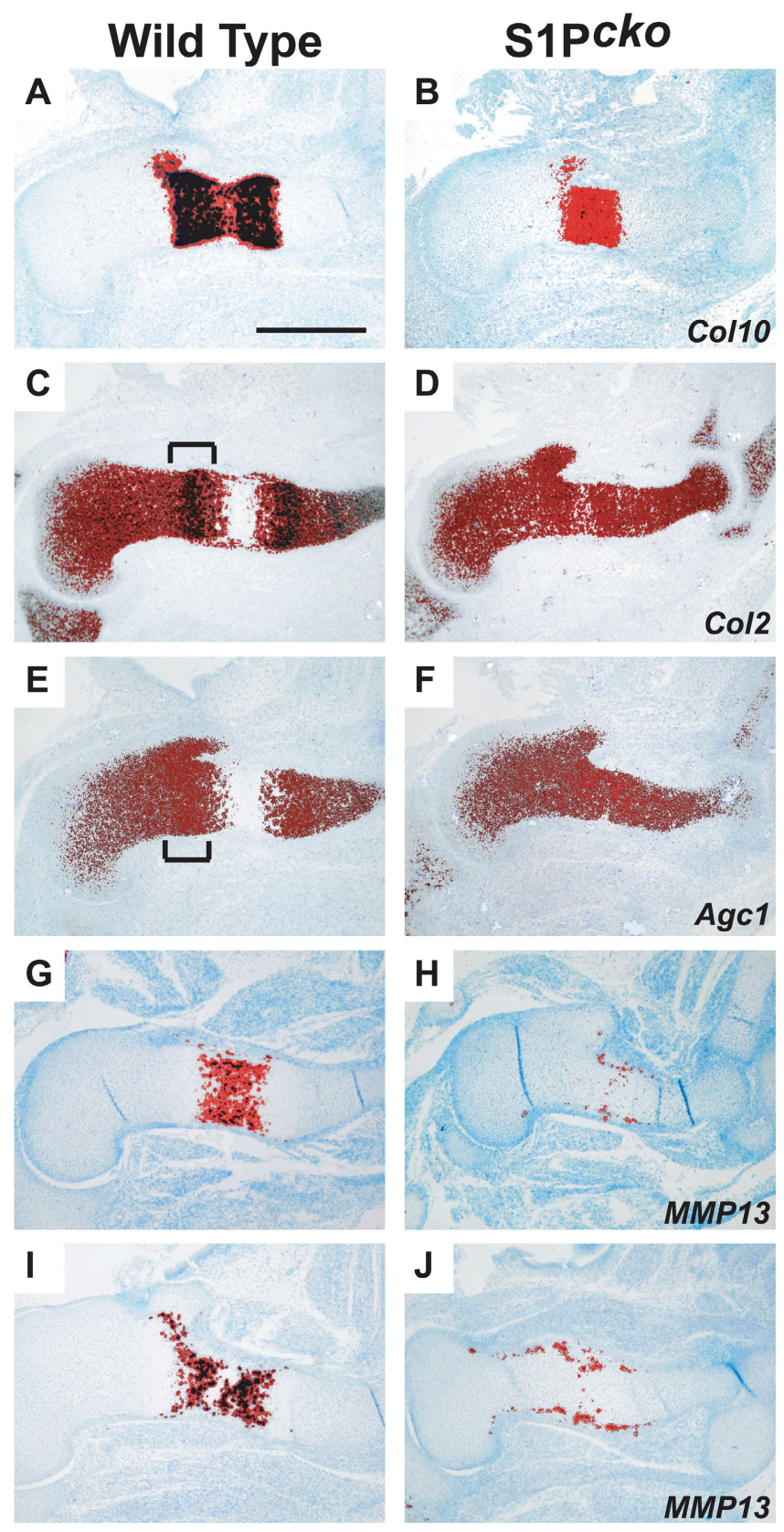

Figure 6. Incomplete hypertrophic chondrocyte differentiation in S1Pcko mice. In situ hybridization analyses for Col10 (A and B), Col2 (C and D), Agcl (E and F), and MMP13 ( $G$ and $H$ ) on humerus sections at $E 14.5$ and for MMP13 at E15.5 (I and J). High expression of $\mathrm{Col} 2$ and $\mathrm{Agcl}$ in the region of columnar chondrocytes (brackets) is absent in S1Pcko mice. Expression of $\mathrm{Col} 2$ and $\mathrm{AgCl}$ continues into the zone of CollO-expressing cells in the S1Pcko humerus. Terminal hypertrophic differentiation, though initiated in some chondrocytes, is absent in S1 Pcko mice, as seen by lack of MMP13 expression. Bar, $500 \mu \mathrm{m}$.

In $\mathrm{S}^{\mathrm{P}} \mathrm{P}^{c k}$ mice, however, such well-defined regions are absent. Zones expressing Ihh (Fig. 5 F), PTHrP-R (Fig. $5 \mathrm{H}$ ), and CollO (Fig. 5 J) largely overlap each other. Thus, even though $I h h$, Runx2, and Collo are expressed, which indicates hypertrophic differentiation, the characteristic hypertrophic cell morphology and organization is missing in $\mathrm{S} 1 \mathrm{P}^{c k o}$ mice.

These results indicate that the loss of S1P does not prevent the molecular program necessary for hypertrophic differentiation.
Rather, the loss of S1P appears to affect cell morphology and may affect matrix production. Therefore, we analyzed the expression of the matrix genes Col2 and aggrecan $(\mathrm{AgCl})$ and MMP13 and Collo in the E14.5 humerus (Fig. 6). At E14.5, chondrocyte hypertrophy is clearly established in the WT, characterized by the expression of $\mathrm{CollO}$ (Fig. $6 \mathrm{~A}$ ) and the lack of Col2 (Fig. 6 C) and $\mathrm{Agcl}$ (Fig. 6 E) expression in hypertrophic cells. In S1P ${ }^{c k o}$ mice, however, expression of Col2 (Fig. $6 \mathrm{D}$ ) and $\mathrm{Agcl}$ (Fig. 6 F) is maintained into the zone of CollOexpressing cells (Fig. 6 B). Thus, in S1P ${ }^{c k o}$ mice, expression of hypertrophic markers is seen concomitantly with expression of markers for proliferating cells. However, the high levels of Col2 and $\mathrm{Agcl}$ expression seen in the columnar cells in WT mice (Fig. 6, C and E, brackets) are absent in S1P ${ }^{c k o}$ mice. Exit from the cell cycle and the expression of Runx2 and Collo suggest hypertrophic differentiation. But the lack of characteristic hypertrophic morphology and the persistence of $I h h, P T H r P-R$, $\mathrm{Col}$, and $\mathrm{AgCl}$ into the Coll0-expressing zone suggest that organized transitions between various cell types are missing; the cells do not respond cohesively to differentiation signals and are therefore unable to organize themselves into structurally discrete zones. Finally, we checked for expression of MMP13 at E14.5 in S1P $\mathrm{P}^{\text {cko }}$ cells. MMP13 is normally expressed by the terminal hypertrophic cells in the growth plate (Colnot et al., 2004). WT mice showed considerable expression of MMP13 (Fig. $6 \mathrm{G}$ ) in the terminal hypertrophic chondrocytes. However, S1P ${ }^{c k o}$ mice exhibit a dramatic decrease in MMP13 expression in the humerus at E14.5 (Fig. $6 \mathrm{H}$ ). This decrease is not a reflection of delay in differentiation but is maintained at E15.5 in S1P ${ }^{c k o}$ mice (Fig. $6 \mathrm{~J}$ ), which suggests a defect in terminal hypertrophic differentiation. However, MMP13 expression was observed in the perichondrium of S1P $\mathrm{P}^{c k o}$ mice at E15.5 presumably in the osteoblasts in the exuberant bone collar. These data suggest that S1P is required for the completion of hypertrophic differentiation and organization of the hypertrophic zone.

\section{Vascular invasion of skeletal elements is absent in S1Pcko mice}

As demonstrated in the preceding section, hypertrophic differentiation remains incomplete in S1P ${ }^{c k o}$ mice. Therefore, we analyzed posthypertrophic differentiation events. Hypertrophic differentiation is usually accompanied by the mineralization of the ECM, allowing for vascular invasion in a VEGF-dependent manner followed by the removal of hypertrophic cells by apoptosis (Zelzer et al., 2002). Extensive mineralization of the ECM, as analyzed by von Kossa staining, was observed in both the E15.5 tibia (Fig. 7 B) and humerus (Fig. 7 D) of S1 $\mathrm{P}^{c k o}$ mice, providing a prelude to vascular invasion. In $\mathrm{S} \mathrm{P}^{c k o}$ mice, however, extensive abnormal mineralization of the chondrocytes in the humerus and to some extent in the tibia is also seen. Abnormal mineralization is often associated with an increase in apoptosis, which leads to the release of apoptotic bodies (Kirsch et al., 2003). Using a TUNEL assay, we studied apoptosis in the forelimbs of WT and S1P ${ }^{c k o}$ mice at E13.75, 14.5, and 15.5. A considerable increase in chondrocyte apoptosis is observed in both the humerus (Fig. 7 F) and scapula (Fig. $7 \mathrm{H}$ ) in S1P $\mathrm{P}^{c k o}$ mice as compared with the WT at E15.5, but not at E13.75 

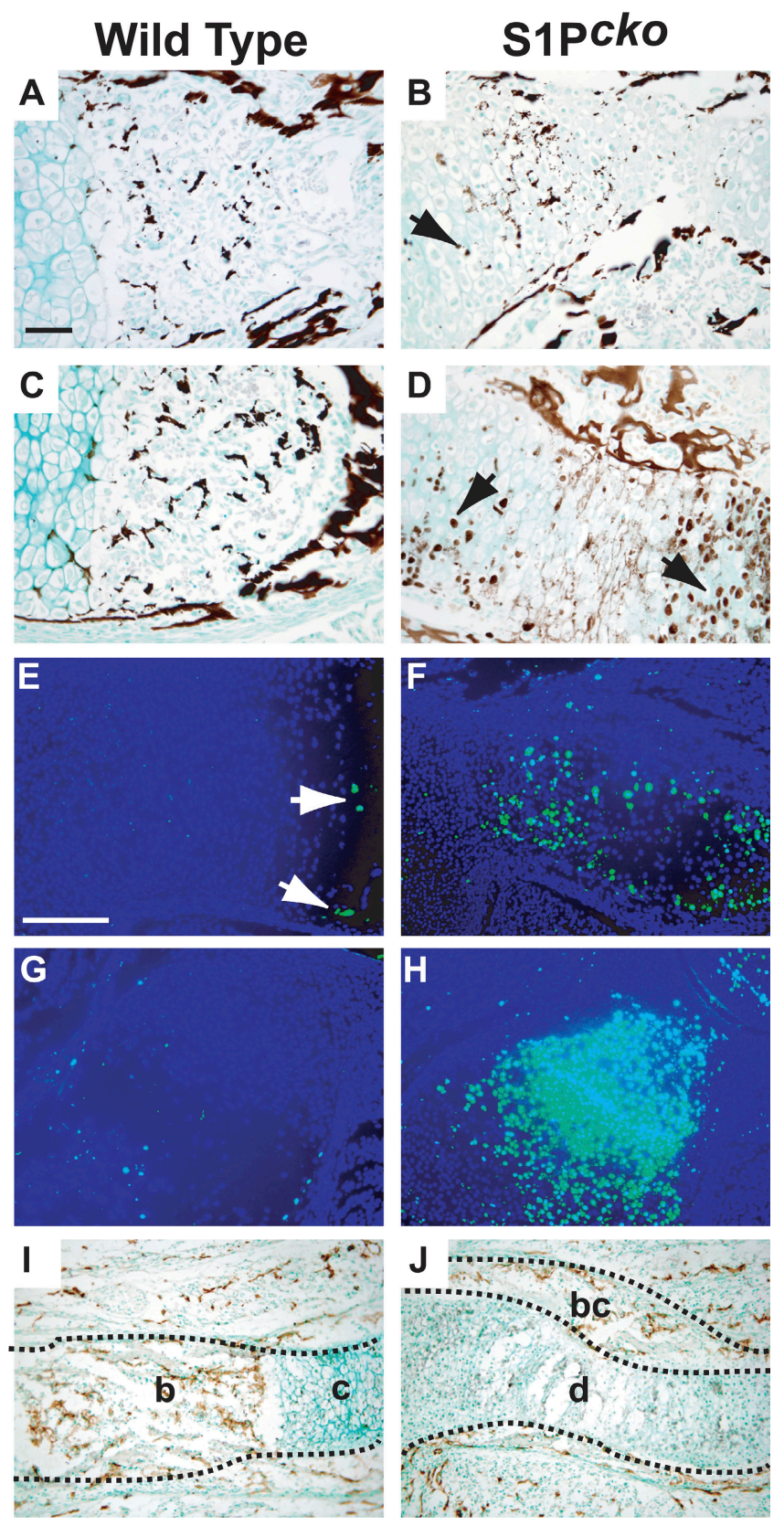

Figure 7. Increased chondrocyte apoptosis and absence of vascular invasion in the skeletal elements of SIPcko mice. von Kossa staining of the tibia ( $A$ and $B$ ) and humerus ( $C$ and $D$ ) at E 15.5, suggesting normal mineralization of the ECM in S1Pcko mice. The black arrows (B and D) depict areas of abnormal mineralization. Increased chondrocyte apoptosis as detected by

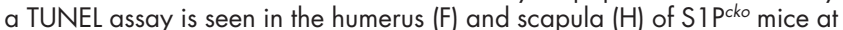
E15.5. In E15.5 WT humorus (E) or scapula (G), hardly any apoptosis is observed; some apoptosis is seen at the chondroosseous junction in the humerus ( $E$, white arrows). (I) PECAM-1 IHC showing the presence of blood vessels in the developing bone (b) of the WT humerus and its absence in the cartilage (c) at E15.5. (J) PECAM-1 staining is absent in the diaphysis (d) of the S1Pcko humerus at E15.5 but is evident in the anomalous bone collar (bc). The dotted lines in panels I and J demarcate the humerus from the surrounding tissue and also outline the bone collar in the mutant. Bars: (A-D) $50 \mu \mathrm{m}$; (E-J) $200 \mu \mathrm{m}$.

or 14.5. Next, we performed immunohistochemistry (IHC) for the platelet/endothelial cell adhesion molecule 1 (PECAM-1) antigen to analyze vascular invasion of the mineralized matrix.
The WT humerus showed normal vascular invasion demarcating the bone from the nonvascular cartilaginous ends (Fig. 7 I). PECAM-1 staining is absent within the humerus in $\mathrm{S}_{1} \mathrm{P}^{c k o}$ mice, suggesting a lack of vascular invasion (Fig. $7 \mathrm{~J}$ ); however, it is seen in the bone collar, suggesting a defect only in endochondral bone formation.

Vascular invasion takes place in a VEGF-dependent manner and is needed for the invasion of osteoblastic progenitors and osteoclasts (Ortega et al., 2003). Osteoblasts synthesize MMP13 (collagenase) and osteoclasts synthesize MMP9 (gelatinase). The cooperative activity of these two MMPs breaks down the mineralized matrix of the hypertrophic cells and replaces it with bone matrix that is rich in Col I ( Vu and Werb, 2000). Interestingly, both WT and $\mathrm{S} 1 \mathrm{P}^{c k o}$ mice demonstrated considerable VEGF and MMP9 expression (Fig. S3, available at http:// www.jcb.org/cgi/content/full/jcb.200708092/DC1). The presence of $M M P$ 9-positive osteoclasts in $\mathrm{S} \mathrm{P}^{\text {cko }}$ mice was further confirmed by tartrate-resistant acid phosphatase-positive cells in the bone collar (Fig. S3). Because of the lack of endochondral bone development in $\mathrm{S}_{1} \mathrm{P}^{c k o}$ mice, we analyzed whether $\mathrm{S}^{\mathrm{P}} \mathrm{P}^{c k o}$ mice have a defect in osteoblast formation. Osteoblastogenesis would be expected to be normal in the mutants because of the proper onset of BSP-expressing bone collar (Fig. $4 \mathrm{I}$ ) and the expression of Runx2 (Fig. 5 D). To extend these findings, we analyzed the expression of Coll, the bone-specific osteocalcin, and alkaline phosphatase, which is vital to bone morphogenesis, in $\mathrm{S} \mathrm{P}^{\text {cko }}$ mice (Fig. S3). Expression of Col1, osteocalcin, and alkaline phosphatase is observed in $\mathrm{S} \mathrm{P}^{c k o}$ mice, though only in the bone collar because of the lack of endochondral bone. These observations indicate that $\mathrm{S}_{1} \mathrm{P}^{c k o}$ mice have the ability to produce normal osteoblast progenitors and that the lack of endochondral bone is caused by the inability of the cartilage matrix to support osteoblast invasion.

\section{Abnormal Col II properties in S1Pcko mice}

Several lines of evidence suggest that matrix abnormalities are primarily responsible for the $\mathrm{S} \mathrm{P}^{c k o}$ phenotype. First, chondrocytes are more densely packed in $\mathrm{S} \mathrm{P}^{c k o}$ skeletal elements. Second, Ihh signaling is intact, as indicated by Ptc- 1 and PTHrP expression, although $P t c-1$ expression appears to be slightly disorganized. Third, it is unlikely that the reduced MMP13 expression seen in $\mathrm{S}_{1} \mathrm{P}^{c k o}$ mice is responsible for the lack of endochondral bone, as the targeted inactivation of MMP13 in mice does not prevent endochondral bone formation (Inada et al., 2004; Stickens et al., 2004). Finally, the increase in chondrocyte apoptosis in $\mathrm{S}_{1} \mathrm{P}^{c k o}$ mice that is suggestive of an abnormal matrix is also seen in transgenic mice lacking Col II (Yang et al., 1997). S1P may thus play a role in the deposition of a normal cartilage. To assess abnormalities in the matrix, we studied the properties of the Col II protein, which is a major cartilage component. First, we attempted to extract the Col II protein from E17.5 WT and $\mathrm{S} \mathrm{P}^{c k o}$ cartilage by pepsin digestion after extraction of the proteoglycans by $4 \mathrm{M} \mathrm{Gu}-\mathrm{HCl}$. After pepsin digestion, the extract was concentrated and equal concentrations of protein from each sample were subjected to SDS-PAGE and analyzed by Western blotting for Col II (using the IIF antibody that detects the triple helical domain of $\mathrm{Col}$ II) and $\mathrm{Col} \mathrm{X}$ protein (Fig. $8 \mathrm{~A}$ ). 
A
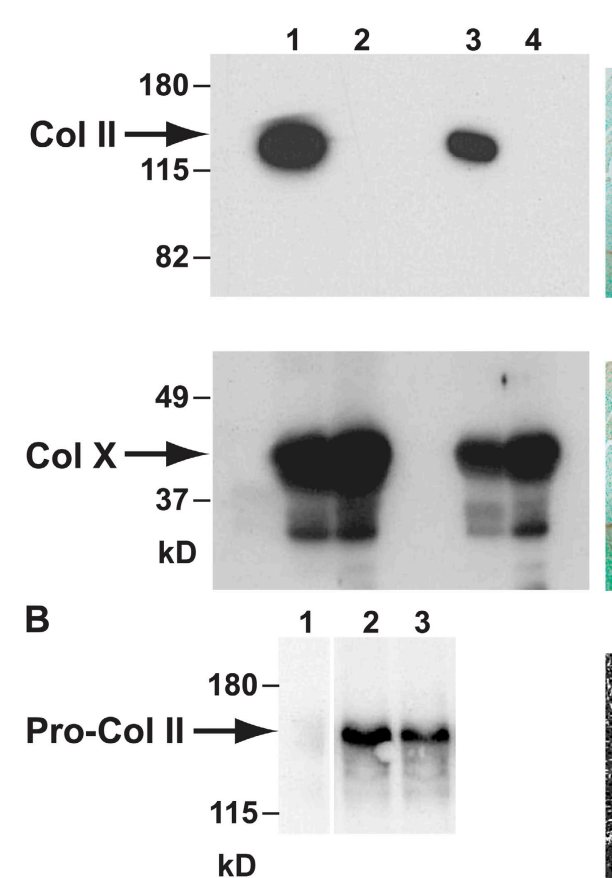

Wild Type
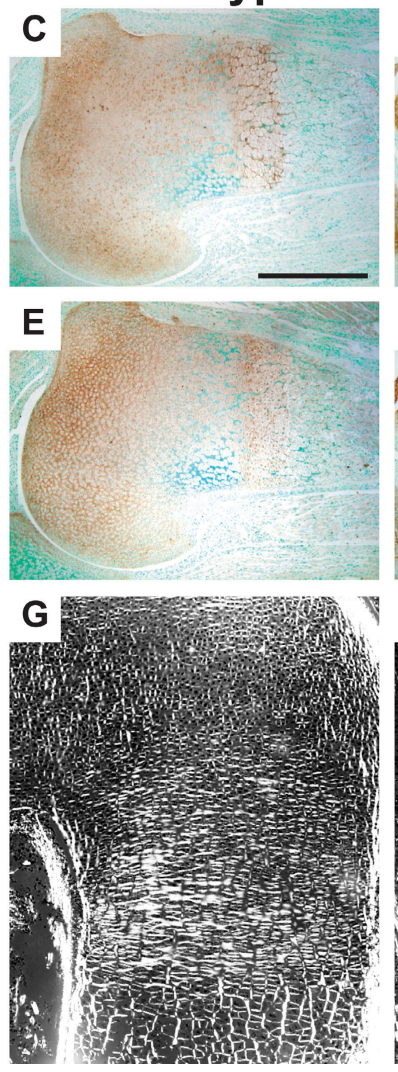

S1Pcko
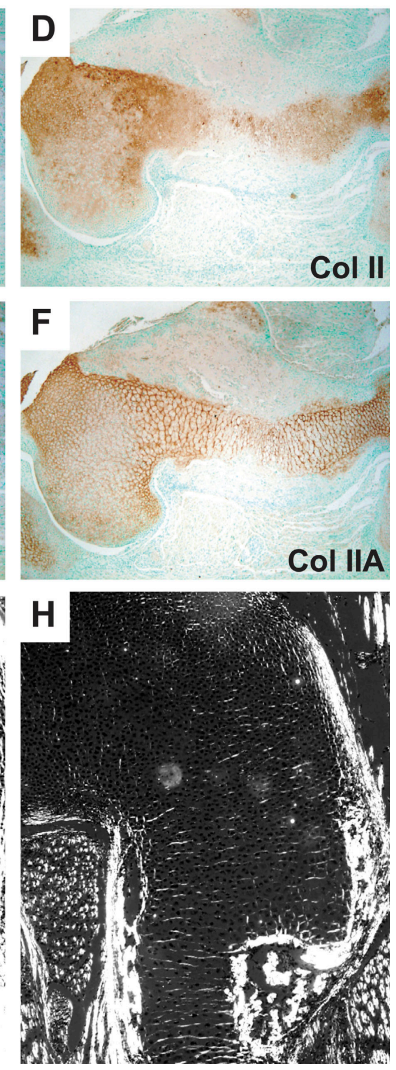

Figure 8. Abnormal Col II properties in S1Pcko mice. (A) The cartilage from the spine and limbs (1 and 2) or head (3 and 4) of WT (1 and 3) and S1Pcko (2 and 4) mice were pepsin digested after extraction of the proteoglycans with $\mathrm{Gu}-\mathrm{HCl}$. The pepsin-released collagens were concentrated and analyzed by SDS-PAGE and Western blotted for Col II (top) and Col X (bottom) proteins. (B) Western blot analysis for the Col II procollagen (Pro-Col II) from the medium of WT (2) or SIPcko (3) chondrocyte cultures (1 is control medium before the addition of chondrocytes). IHC for the Col II (C and D; IIF antibody) and Col IIA (E and F; IIA antibody) proteins demonstrating their expression in the mutant mice. Detection of protein was performed with DAB. Polarized light microscopy to analyze the birefringence properties of the Col Il fibrillar network in the E 16.5 humerus of WT (G) and S IPcko (H) mice. White line in B indicates that intervening lanes have been spliced out. Bar, $500 \mu \mathrm{m}$.

We were able to extract the full-length Col II from the WT head (Fig. 8 A, lane 3) and the rest of its skeleton (Fig. 8 A, lane 1). Notably, we were not able to extract the full-length Col II from any of the S1P ${ }^{c k o}$ skeletal elements (Fig. 8 A, lanes 2 and 4). In some preparations, some lower molecular weight proteins with immunoreactivity to the IIF antibody are seen (unpublished data). But we were unable to extract comparable amounts of the full-length Col II protein in any of our attempts. By Western blotting analysis of twofold dilutions of the pepsin-digested material, we determined that we were extracting $\sim 64$-fold less of the full-length Col II protein from the $\mathrm{S}_{1} \mathrm{P}^{c k o}$ mice as compared with WT (unpublished data). In contrast, we were able to extract comparable amounts of the Col X protein from both WT and $\mathrm{S}_{1} \mathrm{P}^{c k o}$ mice.

These data suggested that the Col II protein is less abundant or absent in S1P ${ }^{\text {cko }}$ mice. However, we were able to detect the full-length Col II procollagen in the medium of cultured chondrocytes from both E18.5 WT and S1P ${ }^{c k o}$ mice by Western blotting (Fig. 8 B). Furthermore, by IHC analysis, Col II protein was detected in the humerus of E18.5 WT (Fig. $8 \mathrm{C}$ ) and S1P $\mathrm{P}^{c k o}$ (Fig. 8 D) mice. We also tested for the presence of the Col IIA protein (using the IIA antibody that detects exon 2), which is normally detected in the matrix surrounding chondroprogenitor cells and early immature chondrocytes. The Col IIA isoform was detected in both WT (Fig. 8 E) and S1P ${ }^{c k o}$ mice (Fig. 8 F). In the WT, detection of Col IIA protein was strongest at the location of the early, immature chondrocytes close to the articular surface. Surprisingly, in S1P ${ }^{c k o}$ mice, Col IIA was detected throughout the length of the humerus (Fig. 8 F). Therefore, we analyzed whether alternative splicing of the procollagen mRNA from Col $2 A$ to Col $2 B$ was normal in $\mathrm{S} 1 \mathrm{P}^{c k o}$ mice. For this analysis, we performed in situ hybridization using highly specific 24-mer oligonucleotide probes spanning the exon 1 and 2 junction for Col $2 A$ analysis and the exon 1 and 3 junction for the $C o l 2 B$ analysis. Splicing of both Col $2 A$ and $2 B$ mRNA was, however, found to be normal in S1P ${ }^{c k o}$ mice (Fig. S4, available at http://www.jcb .org/cgi/content/full/jcb.200708092/DC1). These data suggested that Col II synthesis was taking place in $\mathrm{S}^{\mathrm{P}} \mathrm{P}^{\text {cko }}$ mice, although the turnover of Col II is abnormal, as total Col II and Col IIA was detected throughout the length of the humerus. These data also suggested that the organization of the cartilage ECM may be abnormal. Therefore, to assess the structural organization of the collagens in the ECM, we first determined the birefringent properties of the Col II fibrils in both WT and S1P $\mathrm{P}^{c k o}$ mice. A marked 

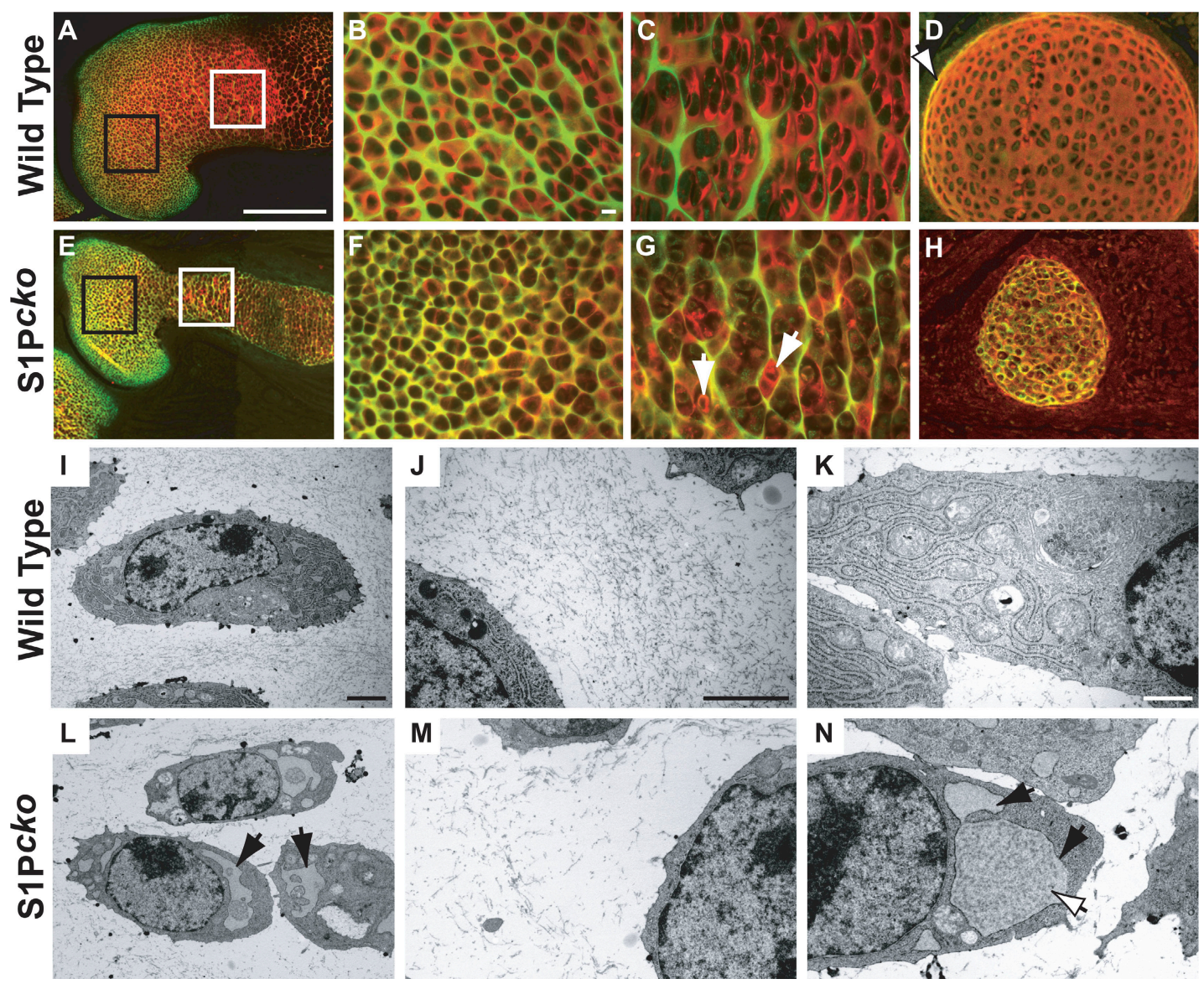

Figure 9. Abnormal collagen fibril deposition and ER stress in S1Pcko mice. Double-labeled immunofluorescence studies with the IIA and IIF antibodies in the $E 15.5$ humerus $(A-C$ and $E-G)$ and $E 18.5$ rib cross sections $(D$ and $H)$ in WT $(A-D)$ and S1 Pcko $(E-H)$ mice showing abnormal collagen fibril deposition and entrapment of $\mathrm{Col}$ IIB protein (G, arrows) within the cell in the mutant mice. $B$ and $F$ are higher magnification images of the regions outlined by the black boxes in $A$ and $E$, and $C$ and $G$ are higher magnification images of the regions outlined by the white boxes. In the WT, colocalization of IIA and IIF antibodies is seen only at the rim of the rib (D, arrow). Colors represent antibody localizations as follows: green, Col II exon 2 (IIA); red, Col II triple helical domain (IIF); yellow, colocalization of both antibodies. Electron microscopy images of the cartilage matrix and chondrocytes of the proliferative zone in E15.5 WT (I-K) and S1Pcko (L-N) tibia. J and M emphasize the cartilage ECM, showing the decrease in collagen fibrillar density in the S1 Pcko matrix, and $\mathrm{K}$ and $\mathrm{N}$ emphasize the intracellular organization, particularly the engorged and fragmented $E R$ in the mutant mice (black arrows). The engorged ER in the mutant is filled with materials that appear homogenously or heterogeneously stained with partially crystalline appearance ( $N$, white arrow). Bars: (A and $E$ ) $500 \mu \mathrm{m}$; (B-D and F-H) $84 \mu \mathrm{m}$; (l and L) $2 \mu \mathrm{m}$; (J and $M) 2 \mu \mathrm{m}$; (K and N) $1 \mu \mathrm{m}$.

decrease in the birefringence of the collagen network was observed in the E16.5 humerus in S1P ${ }^{c k o}$ mice (Fig. $8 \mathrm{H}$ ) as compared with the WT (Fig. $8 \mathrm{G}$ ), which suggests a poorly organized collagen fibrillar network in the cartilage of S1P $\mathrm{P}^{c k o}$ mice. This reduced birefringence in $\mathrm{S}^{\mathrm{c}} \mathrm{P}^{c k o}$ mice is similar to that seen in mice with inactivation of the Col2al gene (Li et al., 1995). These data together suggest that one of the molecular defects caused by a lack of S1P is the abnormal organization of the Col II protein, which results in an abnormal cartilage that prevents vascular invasion and endochondral ossification in S1 $\mathrm{P}^{c k o}$ mice.

To pursue this observation further, we performed doublelabeled immunofluorescence analysis with the IIA and IIF antibodies (Zhu et al., 1999) to study the organization and localization of the Col II protein (Fig. 9). In the WT, the secretion and incorporation of Col IIA into the matrix is seen as a well-formed and organized green lattice network. Localization of the collagen triple helical domains is seen as red immunofluorescence, which in the WT is seen as a distinct red lattice network with hardly any yellow colocalization signals from the two anti- bodies, suggesting that the red lattice is almost entirely made of Col IIB protein. As expected in the WT, the presence of Col IIA is stronger in the matrix surrounding the early immature chondrocytes (Fig. 9 B) and the presence of Col IIB is stronger around the more mature columnar chondrocytes (Fig. 9 C). In S1P ${ }^{c k o}$ mice (Fig. 9, F and G), the organization of the Col IIA lattice network appears normal, though it is also prominent in the matrix surrounding mature chondrocytes (Fig. 9 G). However, in the matrix surrounding early chondrocytes (Fig. 9 F), well-formed organization of Col IIB fibrils (red) is considerably reduced and the majority of the signal appears to be caused by colocalization (yellow), suggesting that both antibodies are detecting primarily Col IIA and very little Col IIB. In the matrix surrounding more mature chondrocytes (Fig. 9 G), the lattice network is primarily green with very little incorporation of Col IIB (red signaling) into the lattice network of the ECM. Most of the Col IIB protein (Fig. 9 G, arrows) is seen trapped inside the cell. The lack of matrix accumulation can be seen more clearly in cross sections of the ribs (at E18.5) in S1P $\mathrm{P}^{c k o}$ 
mice (Fig. 9 H). Again, primarily colocalization signals (yellow) and the substantial absence of matrix when compared with the WT (Fig. 9 D) is observed, which showed abundant matrix (red) with yellow colocalization signals restricted to the rim of the rib.

These data suggested that in $\mathrm{S}^{\mathrm{P}} \mathrm{P}^{c k o}$ mice, although there is no problem in the expression and secretion of Col IIA and its incorporation into the matrix, the expression and/or secretion of Col IIB is abnormal and results in a matrix with considerably reduced levels of Col IIB and therefore an inability to extract Col II from the matrix (Fig. 8 A). To understand the mechanism for this defect, we performed electron microscopic analysis of tibia (Fig. 9, I-N) and humerus (not depicted) from E15.5 WT and $\mathrm{S} \mathrm{P}^{c k o}$ mice. In the WT (Fig. 9, I-K), the cartilage from the proliferative zone showed the presence of well-formed and abundant, homogenous Col II fibrils surrounding normal chondrocytes. In S1P ${ }^{c k o}$ mice, however (Fig. 9, L-N), the distribution of collagen fibril density is irregular and considerably reduced. The ER is drastically enlarged, irregular in shape, and fragmented and also often found filled with granular, homogenous, or heterogenously stained material that also sometimes appears to be crystalline. Similar observations were seen in the chondrocytes/ECM of the articular, hypertrophic, and joint cartilage regions in $\mathrm{S}_{1} \mathrm{P}^{c k o}$ mice. These data suggest the induction of ER stress in chondrocytes in $\mathrm{S}_{1} \mathrm{P}^{c k o}$ mice, presumably caused by the excessive demand for complex matrix protein synthesis required for cartilage deposition, and a requirement for S1P activity to alleviate ER stress during matrix protein synthesis and deposition.

\section{Discussion}

In this paper, we have established the importance of S1P to cartilage deposition and endochondral ossification. Null mice with a loss of S1P in all tissues were found to be embryonic lethal at a very early stage and therefore did not provide a suitable avenue to study its contribution to cartilage and bone development (Yang et al., 2001). Our studies on S1P ${ }^{c k o}$ mice have allowed us to focus on the requirement of S1P in chondrocyte differentiation and the genesis of a normal endochondral skeleton. Cartilagespecific disruption of S1P in S1P ${ }^{c k o}$ mice results in total lack of endochondral bone in all skeletal elements that exhibit longitudinal bone growth through endochondral ossification.

The lack of endochondral bone seen in $\mathrm{S}^{\mathrm{P}} \mathrm{P}^{c k o}$ mice is also seen in Ihh (St-Jacques et al., 1999) and Runx2 null mice (Komori et al., 1997; Otto et al., 1997). In both these mutants, endochondral bone development is hampered because of a defect in osteoblastogenesis. Both Ihh and Runx2 null mice also suffer from varying degrees of an abnormal chondrocyte differentiation program (Inada et al., 1999; Kim et al., 1999). In S1P ${ }^{c k o}$ mice, we initially expected that the phenotype could have arisen because of a defect in the Ihh signaling pathway. However, our data suggest that $\mathrm{S} \mathrm{P}^{c k o}$ mice have an intact Ihh signaling pathway, as indicated by the expression of Ptc-1 and PTHrP in $\mathrm{S}^{\mathrm{P}} \mathrm{P}^{c k o}$ skeletal elements. However, the mislocalization of Ptc-1expressing cells leaves open the possibility that S1P has an effect on the activity level and/or diffusion of Ihh. The morphological phenotype that sets $\mathrm{S} \mathrm{P}^{c k o}$ mice apart from Ihh and Runx2 null mice is that $\mathrm{S}_{1} \mathrm{P}^{c k o}$ mice exhibit an exuberant bone collar show- ing normal osteoblastogenesis. Elimination of S1P results in an uncoupling of normal endochondral bone formation from cortical bone formation. Thus, like Ihh and Runx2, S1P is a major positive regulator of endochondral ossification. Expression of SIP is observed in the perichondrium in the WT. However, in $\mathrm{S}_{1} \mathrm{P}^{c k o}$ mice, S1P activity would be expected to be absent in the perichondrium because of active Col2-Cre activity in these cells. These data suggest that S1P is not necessary for cortical bone formation. Mice with double knockouts of the transcription factors L-Sox5 and Sox6 also exhibit a lack of endochondral ossification with development of a thick cortical bone (Smits et al., 2001). However, it is unlikely that this pathway is affected in $\mathrm{S} \mathrm{P}^{c k o}$ mice, as they exhibit abundant expression of L-Sox 5 and Sox6 (unpublished data).

The lack of endochondral bone in $\mathrm{S} \mathrm{P}^{c k o}$ mice appears to be caused by an inability of the blood vessels to invade the abnormal, mineralized cartilage in spite of apparently adequate $V E G F$ expression. According to the tenets of organogenesis, where development is guided by tissue interactions, the developmental history of a tissue plays an important role in its ability to respond to instructive cues (De Robertis, 2006). Thus, it would be expected that an abnormal cartilage would constrain its ability to respond to instructions from the perichondrium and/or vascular tissue. The genesis of a normal matrix is necessary for proper hypertrophic differentiation and endochondral ossification. Our data suggest that the defects in hypertrophic differentiation and endochondral ossification can be traced to an abnormal matrix in $\mathrm{S} \mathrm{P}^{c k o}$ mutants. In $\mathrm{S}^{\mathrm{P}} \mathrm{P}^{c k o}$ mice, the chondrocytes are densely packed and randomly oriented with very little matrix between them. The increased chondrocyte apoptosis seen in $\mathrm{S}^{\mathrm{c}} \mathrm{P}^{c k o}$ mice is also highly indicative of an abnormal cartilage that is unable to support chondrocyte survival. This is similar to the increased apoptosis seen in transgenic mice lacking Col II (Yang et al., 1997). The absence of a proper cartilage could hinder not only the supply of nutrients to the avascular ECM (Hunziker and Herrmann, 1990) but also have profound effects on integrin-mediated pathways and distribution of growth factors (Yoon and Fisher, 2006). The inability to extract normal amounts of full-length Col II from cartilage, the decreased birefringence of Col II network, the lack of the Col IIB lattice network, and the considerable reduction in collagen fibrillar density as seen by electron microscopy all attest to the fact that the cartilage is abnormal in $\mathrm{S}_{1} \mathrm{P}^{c k o}$ mice. $\mathrm{S} 1 \mathrm{P}^{c k o}$ mice also exhibit abnormal spine development in that the intervertebral discs are not well formed and lack the gelatinous nucleus pulposus in the center. This is also seen in transgenic mice with a null mutation in the Col2al gene (Aszodi et al., 1998).

An abnormal cartilage ECM could mask angiogenic signaling by VEGF in spite of the adequate $V E G F$ expression that is seen in $\mathrm{S} \mathrm{P}^{c k o}$ mice. Given the abnormal characteristics of the cartilage matrix, even if VEGF is not masked, the MMPs may not be able to process and break down the alien matrix in $\mathrm{S} \mathrm{P}^{c k o}$ mice. An inability to degrade the matrix is suggested by the persistence of Col IIA in the $\mathrm{S}^{\mathrm{P}} \mathrm{P}^{c k o}$ cartilage, as Col IIA is seen throughout the length of the humerus. These observations are highly suggestive of a lack of structurally intact cartilage matrix in $\mathrm{S}_{1} \mathrm{P}^{c k o}$ mice that is normally a forerunner for endochondral 


\section{Chondroprogenitor/ Periosteal Cells Type IIA Collagen}

\section{Chondrocytes Type IIB Collagen}

\section{Chondrocytes Type IIB Collagen}

\section{Wild Type}

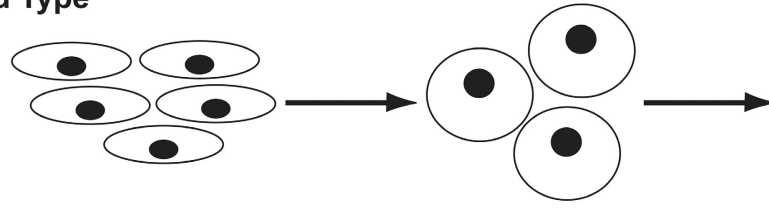

ER Stress

Active TF

No ER Stress

\section{Active ERSS}

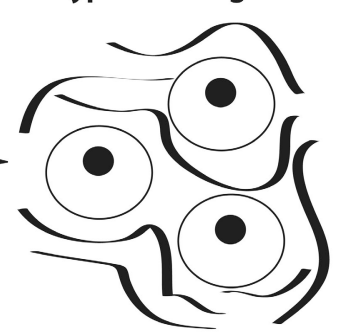

Normal Matrix Deposition Endochondral Ossification
Figure 10. A model for the requirement of SIP in the ER stress response for the genesis of a normal cartilage matrix. TF, transcription factor.

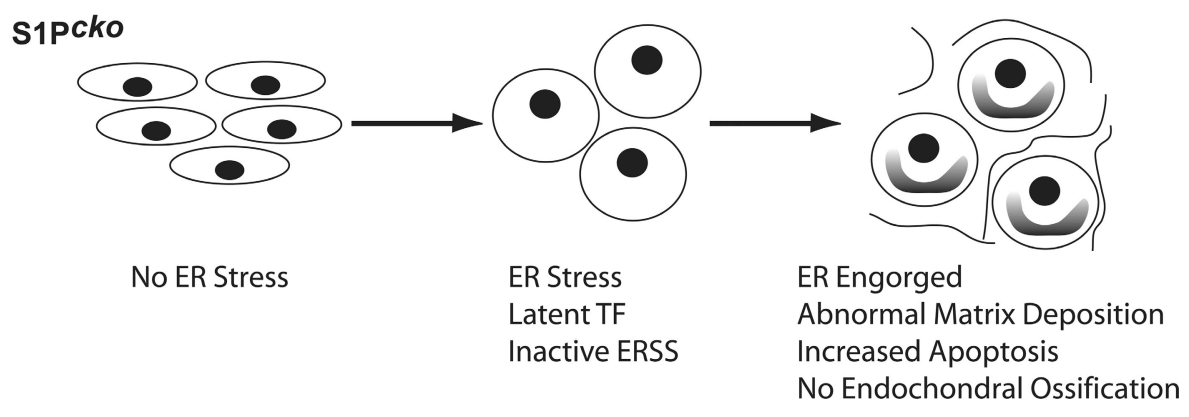

bone development. Some of the phenotypes seen in $\mathrm{S}_{1} \mathrm{P}^{c k o}$ mice also bear resemblance to the phenotypes seen in mutants for other matrix proteins. For example, a lack of columnar hypertrophic chondrocytes, disorganized growth plates, chondrodysplasia, and incomplete nucleus pulposus are seen in mice lacking perlecan (Arikawa-Hirasawa et al., 1999; Gustafsson et al., 2003), Agc1 (Watanabe et al., 1994; Wai et al., 1998), and/or link protein (Watanabe and Yamada, 1999). These observations clearly attest to the importance of a properly organized matrix for chondrocyte differentiation. However, these mutations exhibit only reduced or delayed endochondral ossification. Thus, it is noteworthy that only the disruption of the Col2al gene (Li et al., 1995) results in a complete lack of endochondral ossification as seen in S1P $\mathrm{P}^{\text {cko }}$ mice. These data suggest a convergence of S1P activity with a property of $\mathrm{Col} \mathrm{II}$ in relation to the cartilage matrix.

Thus, our paper shows that S1P is essential to endochondral ossification. The much accepted role of S1P is that of a proprotein convertase required to activate the transcription factors SREBPs, ATF6, OASIS, and CREBH, the latter three playing vital roles during ER stress response. Given that the knockout of the SREBP molecules has not exhibited any known defect in bone morphogenesis in mice that escape embryonic lethality (Shimano et al., 1997; Liang et al., 2002), it seems unlikely that the phenotype in $\mathrm{S}^{c} \mathrm{P}^{c k}$ mice is manifested through SREBPs. Furthermore, in the zebrafish gonzo phenotype, knockdown of SCAP (the lipid sensor) results only in strong lipid phenotypes with normal cartilage (Schlombs et al., 2003). These data suggest that the abnormal cartilage phenotype in $\mathrm{S}_{1} \mathrm{P}^{c k o}$ mice is mediated by lipid-independent pathways. Given the engorgement and fragmentation of the ER in S1P ${ }^{c k o}$ mice, it seems likely that $\mathrm{S} 1 \mathrm{P}$ is required to activate ER stress signaling (ERSS) in response to the hyperproduction of complex cartilage matrix proteins seen in chondrocytes. Unlike other studies (Tsang et al., 2007), it is noteworthy that the ER stress observed in $\mathrm{S}_{1} \mathrm{P}^{c k o}$ mice is not caused by the introduction of any mutant matrix protein but by the inability of the chondrocyte to respond to ER stress because of a lack of S1P activity. Based on these data we propose that the ER stress response is part of the vital protein processing machinery in normal chondrocytes and is essential for normal matrix production (Fig. 10). In a normal chondrocyte differentiation program, chondroprogenitor cells do not require ER stress response because of the relatively low level of protein synthesis and secrete Col IIA into the matrix. However, on differentiation into chondrocytes, to alleviate the stress caused by the high demand for complex matrix protein synthesis, the chondrocytes initiate ERSS, a mechanism that requires S1P to activate ATF6, OASIS, or CREBH (currently the three known ER stress signal transducers that require activation by $\mathrm{S} 1 \mathrm{P})$. This allows for the deposition of normal cartilage followed by endochondral ossification. In S1P ${ }^{c k o}$ mice, chondroprogenitor cells do not show any defect in the secretion of Col IIA either because of the level of Col IIA synthesis or the different dynamics of Col IIA secretion. However, upon differentiation into chondrocytes and a switch to the alternatively spliced form Col IIB and the concomitant increase in protein synthesis and secretion, S1P ${ }^{c k o}$ mice are unable to initiate the ER stress response because of an inability to activate the appropriate transcription factors in the absence of S1P. This results in the engorgement and fragmentation of the ER followed by poor Col IIB secretion into the matrix, which results in the matrix acquiring the properties typically seen on disruption of the Col2al gene. Other cell types, such as the periosteal cells, which lack S1P but do not require the same ER stress response, are able to synthesize bone, as seen in $\mathrm{S}_{1} \mathrm{P}^{c k o}$ mice. Thus, chondrocytes in this respect are like the differentiating plasma cells, which turn on the unfolded protein response to alleviate ER stress and optimize antibody secretion 
(Gunn et al., 2004), or exocrine glands, where the ER stress response is necessary for the full development of the secretory machinery (Lee et al., 2005).

In the zebrafish S1P gonzo mutants, ER stress and unfolded protein response were reported to be normal based on in situ hybridization to two mRNA sequences known to be downstream of ATF6. In light of recent discoveries, this assessment may have been misleading. First, the analysis in gonzo mutants involved the in situ analysis of the full-length XBPI mRNA and not the specific splice form necessary for ER stress response (Yoshida et al., 2001; Calfon et al., 2002). Second, the presence of immunoglobulin heavy chain binding pretien (BiP) chaperone does not ensure an adequate ERSS in chondrocytes, and BiP can be regulated by other transcription factors such as NF-Y (Yoshida et al., 2000). In preliminary experiments, we also detect $\mathrm{BiP}$ expression in both $\mathrm{WT}$ and $\mathrm{S}^{\mathrm{P}}{ }^{c k o}$ mice (unpublished data). Lastly, besides ATF6, at least two other ERSS transcription factors, OASIS and CREBH, are regulated by S1P. Collectively, these observations suggest the requirement of a new specialized pathway for regulation of matrix protein synthesis in chondrocytes. We are currently investigating these possibilities using our mouse model to provide a more complete picture of the utility of S1P in ER stress response, matrix synthesis, and endochondral bone formation.

\section{Materials and methods}

\section{Generation of S1Pcko mice}

To generate S1Pcko mice, S1Pf/f mice (mice homozygous for the S1 Pflox allele in which the exon 2 of SIP is floxed, provided by J.D. Horton, University of Texas Southwestern Medical Center, Dallas, TX; Yang et al., 2001) were bred with Col2-Cre (where the Cre recombinase is under the influence of the cartilage-specific Col2al promoter, limiting its expression primarily to cartilage; a gift of D. Ornitz, Washington University School of Medicine, St. Louis, MO; Jacob et al., 2006) transgenic mice of the C57BL/6J strain to produce S1 $\mathrm{P}^{\mathrm{f} /+}$; Col2-Cre mice (mice heterozygous for the S1 Pflox allele and positive for the Col2-Cre transgene). The S1 $\mathrm{P}^{\mathrm{f}+} ;$;Col2Cre mice were bred with S1 Pf/f mice to generate S1Pcko mice. Genotypes were verified by PCR analysis of tail-derived DNA.

\section{Isolation of collagens from WT and S1Pcko mice}

The isolation of collagens was done from E17.5 WT and S1Pcko mice using a modification of previously published protocols (Mayne et al., 1995). In brief, E17.5 embryos were skinned and eviscerated, and the head was processed separately from the rest of the body. The spine/limbs and head were frozen and crushed, and the proteoglycans were extracted with $4 \mathrm{M}$ Gu- $\mathrm{HCl}$ in $0.05 \mathrm{M}$ Tris- $\mathrm{HCl}$, pH 7.5, containing 0.01 M EDTA and a $1 \times$ complete protease inhibitor cocktail (Roche), for $36 \mathrm{~h}$ at $4^{\circ} \mathrm{C}$. The cartilage residues left after proteoglycan extraction were washed with cold water and digested with $1 \mathrm{mg} / \mathrm{ml}$ pepsin in $0.5 \mathrm{M}$ acetic acid for $24 \mathrm{~h}$ at $4^{\circ} \mathrm{C}$. The digest was then concentrated with centricon30 (Millipore) to $\sim 250 \mu \mathrm{l}$, dialyzed against $0.05 \mathrm{M}$ Tris- $\mathrm{HCl}, \mathrm{pH} 7.5$, buffer containing $0.4 \mathrm{M} \mathrm{NaCl}$ and $5 \mathrm{mM}$ EDTA, and stored at $-20^{\circ} \mathrm{C}$. Equal concentrations of protein preparations (determined by Bio-Rad Laboratories protein assay) from WT and SIPcko mice were separated by SDS-PAGE followed by Western blotting for Col II (using the previously described rat antibody IIF against bovine Col II triple helical domain; Zhu et al., 1999) and Col X proteins (EMD). The molecular weight marker used in SDS-PAGE was BenchMark prestained protein ladder (Invitrogen).

\section{Primary chondrocyte cultures from WT and SIPcko mice}

To study the biosynthesis and secretion of the Col II protein in vitro, primary cultures from WT and S1Pcko mice were established. Chondrocytes were isolated from the sternum and ribs of WT and S1Pcko mice as described previously (Lefebvre et al., 1994). In brief, rib cages were taken from WT or S1Pcko mice and treated with $2 \mathrm{mg} / \mathrm{ml}$ pronase (Roche) at $37^{\circ} \mathrm{C}$ for $30 \mathrm{~min}$ followed by $3 \mathrm{mg} / \mathrm{ml}$ collagenase (Roche) treatment in the pres- ence of $8 \% \mathrm{CO}_{2}$ for $1.5 \mathrm{~h}$ at $37^{\circ} \mathrm{C}$ or until all soft tissues are detached from the cartilage. The cartilage was then separated from the soft tissues and treated again with $3 \mathrm{mg} / \mathrm{ml}$ collagenase for $4 \mathrm{~h}$ at $37^{\circ} \mathrm{C}$ in the presence of $5 \% \mathrm{CO}_{2}$. The digest was filtered through a cell strainer to remove undigested bony parts and the cells were then pelleted by centrifugation, washed with $1 \times$ PBS, and plated at a density of $2.5 \times 10^{5}$ per $\mathrm{cm}^{2}$ in DME with 10\% heat-inactivated serum, 2\% penicillin/streptomycin (SigmaAldrich), and $0.25 \mathrm{mM}$ sodium ascorbate. $50 \mu \mathrm{l}$ of media from the WT and S1Pcko chondrocyte cultures was harvested at regular intervals and separated by $7.5 \%$ SDS-PAGE (Bio-Rad Laboratories), and the type II procollagen was detected by Western blotting using the IIF antibody.

\section{Morphological and histological analysis}

Whole-mount skeletal staining of embryos by alcian blue and alizarin red was performed as described previously (McLeod, 1980). For histological and in situ hybridization analyses on sections, embryonic tissues were collected at various embryonic time points and processed and sectioned as described previously (Hilton et al., 2005). Histological analyses were done primarily by Safranin O, Fast green, and hematoxylin staining. Detection of mineralization was performed by staining with $1 \%$ silver nitrate as per the von Kossa method, followed by counterstaining with Methyl green. In situ hybridization analyses were performed using ${ }^{35}$ S-labeled riboprobes as described previously (Long et al., 2001). All in situ probes with the exception of $\mathrm{Agcl}$ were provided by F. Long (Washington University School of Medicine) and have been described by Hilton et al. (2005) and references therein. The Agcl in situ probe la gift of E. Vuorio, University of Turku, Turku, Finland) covering the IGD sequence of the mouse Agcl has been described previously (Glumoff et al., 1994). The full-length SIP and the SIP exon 2 in situ probes were derived from a full-length CDNA clone (American Type Culture Collection). For BrdU analyses, pregnant females were injected with BrdU as described previously (Hilton et al., 2005), and proliferation of chondrocytes was analyzed using a kit (Invitrogen). For PECAM-1 IHC, embryos were fixed using $4 \%$ formaldehyde followed by $30 \%$ sucrose infiltration. $10-\mu \mathrm{m}$ cryostat sections were derived from tissues embedded in OCT (Tissue-Tek; Thermo Fisher Scientific) and IHC was performed using a monoclonal rat anti-mouse PECAM-1 antibody (BD Biosciences). Detection of PECAM-1 was done using HRP-conjugated anti-rat $\lg G$ and DAB. Methyl green was used for counterstaining. Detection of apoptosis was performed by a TUNEL assay using the in situ cell death detection kit (Roche) according to the manufacturer's instructions. Nuclei were counterstained with DAPI and sections were examined by fluorescence microscopy. Tartrate-resistant acid phosphatase-positive cells were stained using standard procedures with methyl green as counterstain. Study of the birefringence of collagen fibers by polarized light microscopy was done on 5 - $\mu \mathrm{m}$-thick paraffin-embedded sections as described previously (Li et al., 1995). Detection of total Col II protein by IHC was done on 5 - $\mu \mathrm{m}$-thick paraffin-embedded sections at E15.5 and 18.5 stages using the IIF antibody and procedure described previously (Zhu et al., 1999), with the exception that detection was done using an HRP-conjugated goat anti-rat secondary antibody and a DAB substrate (Invitrogen). Detection of Col IIA protein was done similarly with the previously described rabbit antisera against recombinant human type IIA-GST (IIA; Oganesian et al., 1997; Zhu et al., 1999) and an HRP-conjugated goat anti-rabbit secondary antibody. Double-labeled immunofluorescence with IIF and IIA antibodies was performed as described previously (Zhu et al., 1999) on paraffin embedded sections, with the exception that the IIA and IIF antibodies (and their corresponding secondary antibodies) were used sequentially with the IIA antibody and its secondary antibody applied first. The secondary antibodies used were goat anti-rabbit Alexa Flour 488 (Invitrogen) and goat antirat Alexa Fluor 546 (Invitrogen). Images for double immunofluorescence were collected with a $60 \times, 1.4 \mathrm{NA}$ oil immersion objective using either a scanning laser confocal microscope (for E18.5 ribs cross sections; MRC600; Bio-Rad Laboratories) mounted on a microscope (Eclipse E800; Nikon) and LaserSharp 2000 software (Bio-Rad Laboratories) or a camera (2000R Fast1394; Retiga)and Q Capture Pro (for limbs; Qlmaging). All other sections (in situ/histology) were viewed with a microscope (BX51; Olympus) using a $10 \times$ objective (all in situ analysis) or 20 and $40 \times$ objectives (for stained sections or $I \mathrm{HC}$ ), and images were captured with the digital camera (DP70; Olympus) using DP controller software (Olympus). For in situ analysis, pictures of hybridization signals were hued red and superimposed on toluidine blue-counterstained images using Photoshop (Adobe).

\section{Online supplemental material}

Fig. S1 shows the lack of endochondral ossification in the femur, ribs, sternum, and spine of S1Pcko mice. Fig. S2 shows the abnormal hypertrophic 
differentiation in S1 $P^{c k o}$ mice. Fig. S3 shows normal VEGF and MMP9 expression and normal osteoblastogenesis in S1Pcko mice. Fig. S4 shows normal Col2 mRNA splicing in S1Pcko mice. Online supplemental material is available at http://www.jcb.org/cgi/content/full/jcb.200708092/DC1.

We thank Jay D. Horton, Joseph L. Goldstein, Matthew J. Hilton, Fanxin Long, Eero Vuorio, Veronique Lefebvre, David Ornitz, Audrey McAlinden, Karen Lyons, and Stavros Thomopoulus for their generous gifts of mice, cDNA in situ probes, reagents, technical advice, and discussions and comments on the manuscript. We thank Simon Nuessli, Jeannine Wagner, and Tatjana Arpagaus for technical assistance with electron microscopy. We also thank Crystal Idleburg for her assistance with histological analysis.

This work was supported by National Institutes of Health grants ROI AR50847 and RO1 AR36994 to L.J. Sandell and Swiss National Science Foundation grant 320000-1 18205 to E.B. Hunziker.

Submitted: 13 August 2007

Accepted: 15 October 2007

\section{References}

Arikawa-Hirasawa, E., H. Watanabe, H. Takami, J.R. Hassell, and Y. Yamada. 1999. Perlecan is essential for cartilage and cephalic development. Nat. Genet. 23:354-358.

Aszodi, A., D. Chan, E. Hunziker, J.F. Bateman, and R. Fassler. 1998. Collagen II is essential for the removal of the notochord and the formation of intervertebral discs. J. Cell Biol. 143:1399-1412.

Brown, M.S., J. Ye, R.B. Rawson, and J.L. Goldstein. 2000. Regulated intramembrane proteolysis: a control mechanism conserved from bacteria to humans. Cell. 100:391-398.

Calfon, M., H. Zeng, F. Urano, J.H. Till, S.R. Hubbard, H.P. Harding, S.G. Clark, and D. Ron. 2002. IRE1 couples endoplasmic reticulum load to secretory capacity by processing the XBP-1 mRNA. Nature. 415:92-96.

Caplan, A.I., and D.G. Pechak. 1987. The cellular and molecular embryology of bone formation. In Bone and Mineral Research, vol. 5. W.A. Peck, editor. Elsevier, New York. 117-183.

Colnot, C., C. Lu, D. Hu, and J.A. Helms. 2004. Distinguishing the contributions of the perichondrium, cartilage, and vascular endothelium to skeletal development. Dev. Biol. 269:55-69.

De Robertis, E.M. 2006. Spemann's organizer and self-regulation in amphibian embryos. Nat. Rev. Mol. Cell Biol. 7:296-302.

Ducy, P., R. Zhang, V. Geoffroy, A.L. Ridall, and G. Karsenty. 1997. Osf2/Cbfa1: a transcriptional activator of osteoblast differentiation. Cell. 89:747-754.

Eberle, D., B. Hegarty, P. Bossard, P. Ferre, and F. Foufelle. 2004. SREBP transcription factors: master regulators of lipid homeostasis. Biochimie. 86:839-848.

Glumoff, V., M. Savontaus, J. Vehanen, and E. Vuorio. 1994. Analysis of aggrecan and tenascin gene expression in mouse skeletal tissues by northern and in situ hybridization using species specific cDNA probes. Biochim. Biophys. Acta. 1219:613-622.

Gritli-Linde, A., P. Lewis, A. McMahon, and A. Linde. 2001. The whereabouts of a morphogen: direct evidence for short- and graded long-range activity of hedgehog signaling peptides. Dev. Biol. 236:364-386.

Gunn, K.E., N.M. Gifford, K. Mori, and J.W. Brewer. 2004. A role for the unfolded protein response in optimizing antibody secretion. Mol. Immunol. 41:919-927.

Gustafsson, E., A. Aszodi, N. Ortega, E.B. Hunziker, H.W. Denker, Z. Werb, and R. Fassler. 2003. Role of collagen type II and perlecan in skeletal development. Ann. NY Acad. Sci. 995:140-150

Hall, B.K., and T. Miyake. 2000. All for one and one for all: condensations and the initiation of skeletal development. Bioessays. 22:138-147.

Haze, K., H. Yoshida, H. Yanagi, T. Yura, and K. Mori. 1999. Mammalian transcription factor ATF6 is synthesized as a transmembrane protein and activated by proteolysis in response to endoplasmic reticulum stress. Mol. Biol. Cell. 10:3787-3799.

Hilton, M.J., X. Tu, J. Cook, H. Hu, and F. Long. 2005. Ihh controls cartilage development by antagonizing Gli3, but requires additional effectors to regulate osteoblast and vascular development. Development. 132:4339-4351.

Horton, W.A. 1993. Cartilage morphology. In Extracellular Matrix and Heritable Disorder of Connective Tissue. P.M. Royce and B. Steinman, editors. Alan R. Liss, New York. 73-84.

Hunziker, E.B., and W. Herrmann. 1990. Ultrastructure of cartilage. In Ultrastructure of Skeletal Tissues. E. Bonucci and P.M. Motta, editors. Kluwer, New York. 79-109.
Inada, M., T. Yasui, S. Nomura, S. Miyake, K. Deguchi, M. Himeno, M. Sato, H. Yamagiwa, T. Kimura, N. Yasui, et al. 1999. Maturational disturbance of chondrocytes in Cbfa1-deficient mice. Dev. Dyn. 214:279-290.

Inada, M., Y. Wang, M.H. Byrne, M.U. Rahman, C. Miyaura, C. Lopez-Otin, and S.M. Krane. 2004. Critical roles for collagenase-3 (Mmp13) in development of growth plate cartilage and in endochondral ossification. Proc. Natl. Acad. Sci. USA. 101:17192-17197.

Jacob, A.L., C. Smith, J. Partanen, and D.M. Ornitz. 2006. Fibroblast growth factor receptor 1 signaling in the osteo-chondrogenic cell lineage regulates sequential steps of osteoblast maturation. Dev. Biol. 296:315-328.

Kim, I.S., F. Otto, B. Zabel, and S. Mundlos. 1999. Regulation of chondrocyte differentiation by Cbfa1. Mech. Dev. 80:159-170.

Kirsch, T., W. Wang, and D. Pfander. 2003. Functional differences between growth plate apoptotic bodies and matrix vesicles. J. Bone Miner. Res. 18:1872-1881.

Komori, T., H. Yagi, S. Nomura, A. Yamaguchi, K. Sasaki, K. Deguchi, Y. Shimizu, R.T. Bronson, Y.H. Gao, M. Inada, et al. 1997. Targeted disruption of Cbfa1 results in a complete lack of bone formation owing to maturational arrest of osteoblasts. Cell. 89:755-764.

Koziel, L., M. Kunath, O.G. Kelly, and A. Vortkamp. 2004. Ext1-dependent heparan sulfate regulates the range of Ihh signaling during endochondral ossification. Dev. Cell. 6:801-813.

Lanske, B., A.C. Karaplis, K. Lee, A. Luz, A. Vortkamp, A. Pirro, M. Karperien, L.H.K. Defize, C. Ho, R.C. Mulligan, et al. 1996. PTH/PTHrP receptor in early development and Indian hedgehog-regulated bone growth. Science. 273:663-666.

Lee, A.H., G.C. Chu, N.N. Iwakoshi, and L.H. Glimcher. 2005. XBP-1 is required for biogenesis of cellular secretory machinery of exocrine glands. EMBO J. 24:4368-4380.

Lefebvre, V., S. Garofalo, G. Zhou, M. Metsaranta, E. Vuorio, and B. De Crombrugghe. 1994. Characterization of primary cultures of chondrocytes from type II collagen/beta-galactosidase transgenic mice. Matrix Biol. 14:329-335.

Li, S.W., D.J. Prockop, H. Helminen, R. Fassler, T. Lapvetelainen, K. Kiraly, A. Peltarri, J. Arokoski, H. Lui, M. Arita, et al. 1995. Transgenic mice with targeted inactivation of the Col2 alpha 1 gene for collagen II develop a skeleton with membranous and periosteal bone but no endochondral bone. Genes Dev. 9:2821-2830.

Liang, G., J. Yang, J.D. Horton, R.E. Hammer, J.L. Goldstein, and M.S. Brown. 2002. Diminished hepatic response to fasting/refeeding and liver X receptor agonists in mice with selective deficiency of sterol regulatory elementbinding protein-1c. J. Biol. Chem. 277:9520-9528.

Long, F., X.M. Zhang, S. Karp, Y. Yang, and A.P. McMahon. 2001. Genetic manipulation of hedgehog signaling in the endochondral skeleton reveals a direct role in the regulation of chondrocyte proliferation. Development. 128:5099-5108.

Mayne, R., M. Van Der Rest, P. Bruckner, and T.M. Schmid. 1995. The collagens of cartilage (types II, IX, X, and XI) and the type IX-related collagens of other tissues (types XII and XIV). In Extracellular Matrix, A Practical Approach. M.A. Haralson and J.R. Hassell, editors. Oxford University Press, New York. 73-97.

McLeod, M.J. 1980. Differential staining of cartilage and bone in whole mouse fetuses by alcian blue and alizarin red S. Teratology. 22:299-301.

Murakami, T., S. Kondo, M. Ogata, S. Kanemoto, A. Saito, A. Wanaka, and K. Imaizumi. 2006. Cleavage of the membrane-bound transcription factor OASIS in response to endoplasmic reticulum stress. J. Neurochem. 96:1090-1100.

Oganesian, A., Y. Zhu, and L.J. Sandell. 1997. Type IIA procollagen amino-propeptide is localized in human embryonic tissues. J. Histochem. Cytochem. 45:1469-1480.

Ortega, N., D. Behonick, D. Stickens, and Z. Werb. 2003. How proteases regulate bone morphogenesis. Ann. N. Y. Acad. Sci. 995:109-116.

Otto, F., A.P. Thornell, T. Crompton, A. Denzel, K.C. Gilmour, I.R. Rosewell, G.W. Stamp, R.S. Beddington, S. Mundlos, B.R. Olsen, et al. 1997. Cbfa1, a candidate gene for cleidocranial dysplasia syndrome, is essential for osteoblast differentiation and bone development. Cell. 89:765-771.

Poole, A.R. 1991. The growth plate: cellular physiology, cartilage assembly and mineralization. In Cartilage: Molecular Aspects. B.K. Hall and S.A. Newman, editors. CRC Press, Boca Raton, FL. 179-211.

Provot, S., and E. Schipani. 2005. Molecular mechanisms of endochondral bone development. Biochem. Biophys. Res. Commun. 328:658-665.

Schipani, E., B. Lanske, J. Hunzelman, A. Luz, C.S. Kovacs, K. Lee, A. Pirro, H.M. Kronenberg, and H. Juppner. 1997. Targeted expression of constitutively active receptors for parathyroid hormone and parathyroid hormone-related peptide delays endochondral bone formation and rescues mice that lack parathyroid hormone-related peptide. Proc. Natl. Acad. Sci. USA. 94:13689-13694. 
Schlombs, K., T. Wagner, and J. Scheel. 2003. Site-1 protease is required for cartilage development in zebrafish. Proc. Natl. Acad. Sci. USA. 100:14024-14029.

Shimano, H., I. Shimomura, R.E. Hammer, J. Herz, J.L. Goldstein, M.S. Brown, and J.D. Horton. 1997. Elevated levels of SREBP-2 and cholesterol synthesis in livers of mice homozygous for a targeted disruption of the SREBP-1 gene. J. Clin. Invest. 100:2115-2124.

Smits, P., P. Li, J. Mandel, Z. Zhang, J.M. Deng, R.R. Behringer, B. de Crombrugghe, and V. Lefebvre. 2001. The transcription factors L-Sox 5 and Sox6 are essential for cartilage formation. Dev. Cell. 1:277-290.

St-Jacques, B., M. Hammerschmidt, and A.P. McMahon. 1999. Indian hedgehog signaling regulates proliferation and differentiation of chondrocytes and is essential for bone formation. Genes. Dev. 13:2072-2086.

Stickens, D., D.J. Behonick, N. Ortega, B. Heyer, B. Hartenstein, Y. Yu, A.J. Fosang, M. Schorpp-Kistner, P. Angel, and Z. Werb. 2004. Altered endochondral bone development in matrix metalloproteinase 13-deficient mice. Development. 131:5883-5895.

Tsang, K.Y., D. Chan, D. Cheslett, W.C. Chan, C.L. So, I.G. Melhado, T.W. Chan, K.M. Kwan, E.B. Hunziker, Y. Yamada, et al. 2007. Surviving endoplasmic reticulum stress is coupled to altered chondrocyte differentiation and function. PLoS Biol. 5:e44.

$\mathrm{Vu}$, T.H., and Z. Werb. 2000. Matrix metalloproteinases: effectors of development and normal physiology. Genes. Dev. 14:2123-2133.

Wai, A.W., L.J. Ng, H. Watanabe, Y. Yamada, P.P. Tam, and K.S. Cheah. 1998. Disrupted expression of matrix genes in the growth plate of the mouse cartilage matrix deficiency (cmd) mutant. Dev. Genet. 22:349-358.

Watanabe, H., and Y. Yamada. 1999. Mice lacking link protein develop dwarfism and craniofacial abnormalities. Nat. Genet. 21:225-229.

Watanabe, H., K. Kimata, S. Line, D. Strong, L.Y. Gao, C.A. Kozak, and Y. Yamada. 1994. Mouse cartilage matrix deficiency $(\mathrm{cmd})$ caused by a $7 \mathrm{bp}$ deletion in the aggrecan gene. Nat. Genet. 7:154-157.

Yang, C., S.W. Li, H.J. Helminen, J.S. Khillan, Y. Bao, and D.J. Prockop. 1997. Apoptosis of chondrocytes in transgenic mice lacking collagen II. Exp. Cell Res. 235:370-373.

Yang, J., J.L. Goldstein, R.E. Hammer, Y.-A. Moon, M.S. Brown, and J.D. Horton. 2001. Decreased lipid synthesis in livers of mice with disrupted Site-1 protease gene. Proc. Natl. Acad. Sci. USA. 98:13607-13612.

Ye, J., R. Rawson, R. Komuro, X. Chen, U. Dave, R. Prywes, M. Brown, and J. Goldstein. 2000. ER stress induces cleavage of membrane-bound ATF6 by the same proteases that process SREBPs. Mol. Cell. 6:1355-1364.

Yoon, D.M., and J.P. Fisher. 2006. Chondrocyte signaling and artificial matrices for articular cartilage engineering. Adv. Exp. Med. Biol. 585:67-86.

Yoshida, H., T. Okada, K. Haze, H. Yanagi, T. Yura, M. Negishi, and K. Mori. 2000. ATF6 activated by proteolysis binds in the presence of NF-Y (CBF) directly to the cis-acting element responsible for the mammalian unfolded protein response. Mol. Cell. Biol. 20:6755-6767.

Yoshida, H., T. Matsui, A. Yamamoto, T. Okada, and K. Mori. 2001. XBP1 mRNA is induced by ATF6 and spliced by IRE1 in response to ER stress to produce a highly active transcription factor. Cell. 107:881-891.

Zelzer, E., W. McLean, Y.S. Ng, N. Fukai, A.M. Reginato, S. Lovejoy, P.A. D'Amore, and B.R. Olsen. 2002. Skeletal defects in VEGF(120/120) mice reveal multiple roles for VEGF in skeletogenesis. Development. 129:1893-1904.

Zhang, K., X. Shen, J. Wu, K. Sakaki, T. Saunders, D.T. Rutkowski, S.H. Back, and R.J. Kaufman. 2006. Endoplasmic reticulum stress activates cleavage of CREBH to induce a systemic inflammatory response. Cell. 124:587-599.

Zhu, Y., A. Oganesian, D.R. Keene, and L.J. Sandell. 1999. Type IIA procollagen containing the cysteine-rich amino propeptide is deposited in the extracellular matrix of prechondrogenic tissue and binds to TGF- $\beta 1$ and BMP-2. J. Cell Biol. 144:1069-1080. 